\title{
原 著論文
}

\section{大規模水田作経営における作業計画に関わる熟練ノウハウの内容と特徵 一滋賀県の雇用型法人経営を対象にした事例分析一}

\author{
藤井吉隆 $* 1)$ - 南石晃明 2) - 小林 - 3) ・ 小嶋俊彦 1) \\ 1）滋賀県農業技術振興センター７521-1301 滋賀県近江八幡市安土町大中 516 \\ 2）九州大学大学院 ₹ 812-8581 福岡市東区箱崎 6-10-1 \\ 3）鳥取大学 干680-8550 鳥取県鳥取市胡山町南 4丁目 101
}

\begin{abstract}
要旨
本研究は，大規模水田作経営の作業計画に関わる熟練ノウハウの内容と特徵を解明するとともに，雇用型法人 経営における従業員の能力養成方策確立の指針を提示することを目的とする。調査は滋賀県の雇用型法人経営を 対象に実施した。 その結果, 作業計画に関わる知識・技能数はかなり多く, 知識では，(1）農作業と同様に経営 固有知識の占める割合が高く, 多様な状況に応じて使い分ける内容が多いこと, (2) 経営固有知識は知識の固有 性の程度に応じて応用型, 固有型に大別できることなどを明らかにした，また，技能では知的管理系技能が中心 的であり，（1）判断の性質に応じて確定判断型，予測判断型に大別できること，（2）関連する知識・技能や情報 を考慮して総合的に判断する技能であることを明らかにした。 そして, 非熟練者は経営固有知識や知的管理系技 能の習得状況が低く, 雇用型法人経営における従業員の能力養成に際しては, (1) 経営固有知識などの准暗黑知 を形式知化して体系的に整理する取り組み，（2）知的管理系技能の判断に必要な要因の全体像の把握を支援する 取り組み，（3）予測判断型の知的管理系技能の判断に必要な状況変化の予測を支援する取り組及，（4）実践的な OJT（On the Job Training：職場内教育訓練）や計画的な労務管理の実施が重要になることを明らかにし，これら の具体的な取り組み方策を提案した.
\end{abstract}

キーワード

大規模水田作経営, 作業計画, 熟練ノウハウ, 従業員の能力養成

\section{はじめに}

近年, 滋賀県の平坦水田地帯では, 農地流動化の進展に 伴ら大規模な水田作経営の形成が進展している. 2010 年 世界農林業センサスによると滋賀県内の経営耕地面積規模 別の農業経営体数は, 5 ha 以下の農業経営体数が減少する 一方で 5 ha 以上の農業経営体数が増加し, とりわけ 30 ha 以上の規模階層では農業経営体数が 2005 年対比 $90 \%$ 増加 するなぞ，全国平均（21\%増加）と比べて急速なテンポで 大規模水田作経営の形成が進展している.

これらの経営では, 法人経営を中心に非農家出身者など の雇用労働力を活用して経営規模を拡大している点に特徵

* Corresponding Author

E-mail: fujii-yoshitaka@pref.shiga.lg.jp
があり，水田農業の担い手执よび新規就農者の受け皿とし て地域農業の発展に果たす役割への期待が高まっている. 一方, 米価の低迷等により水田作経営を取り巻く経営環境 が悪化する中で, 大規模水田作経営の成長・発展を図る上 ではマーケティング力の強化やコスト削減などへの取り組 みと併せて, 生産活動の基本となる安定した収量・品質を 確保することの重要性が高まって扣り, そのためには, 緻 密な生産管理を実践することが求められる.

しかし, これらの経営では雇用労㗢力の導入が進んでい るにもかかわらず，従業員の能力養成が円滑に進んでいな い事例が散見されるなど, 人材育成の成否が大規模水田作 経営の成長・発展を左右する重要な要因となっている。こ のため, 近年増加する雇用型法人経営の成長・発展を図る 上では，農業生産現場において実践的に活用できる従業員 の能力養成方策の確立が喫緊の課題となっている. 
そこで, 本研究では, 大規模水田作経営の作業計画策定 業務を対象に熟練ノウハウの内容と特徴を解明するととも に, 雇用型法人経営に拈ける従業員の能力養成方策を確立 するための指針を提示する。本研究に関連する既往研究と しては，農業に拈けるナレッジや情報のマネジメントに関 する研究, 知識・技能伝承に関わる研究, 農業経営情報シ ステムの開発に関わる研究などがある.

第一に，農業経営学に和けるナレッジや情報のマネジメ ントに関わる研究として, 間間（2009）は,「今後の農業 経営研究の展開に拈いてナレッジマネジメントは，新しい 問題解決型の農業経営学の柱となる理論であるとともに, 農業経営学が担い手経営組織の発展を支えるといら実践課 題に応えられる理論である」として当該研究の重要性を指 摘している．南石（2011a，p.5）は，「わが国の農業の発展 のためには，広い視点から経営ビジョンを描き，その実現 に向けて経営目的を定め, 経営目標の達成に向けて営農計 画を策定し，日々果敢な挑戦をする先進的な農業経営者の 存在が不可欠である。こうした農業イノベーションを実践 する人材の育成は喫緊の課題であり, それを加速させるた めには, 農業経営者の戦略的な経営行動の参考になる知識 を体系化し，また，経営意思決定を支援する実践的な技術 開発を行ら必要がある」ことを指摘すると共に，具体的な 手法を例示している。 また，南石ら（2012）は，農業経営 にかかわる「情報」,「知識」,「意思決定」,「情報システム」 などに関する研究成果を対象にした文献レビューを行い， 農業経営学扐よび農業情報学に捺いて，知識や情報のマネ ジメントに関する研究が重要になっていることを指摘して いる。間間（2011）は農業経営学分野に打けるナレッジマ ネジメントの主要な研究領域として「暗黙知の探索」,「形 式知の探索」などを提示するとともに，「農業経営におい ては知識・技能が形式知化できるものであっても他人に伝 達可能な形で整理されてこなかった」ことを指摘した上で, 「言語，映像，データなどで伝えることが可能であるが， 熟練者の頭の中にあり形式知化されていないもの」を准暗 黙知と定義している．これに対して，藤井ら（2012）は， 暗黙知，准暗黙知などの区分は相対的なものであり，技術 進歩が著しい情報技術などを活用した新たな手法を確立す ることで，形式知化できる領域の拡大を期待できることを 指摘している. 本研究の目的とする雇用型法人経営に括け る従業員の能力養成を図る上では，藤井ら（2012）が指摘 した認識に立ち，農業経営に打ける暗黙知，准暗黙知の形 式知化支援など, 農業生産現場における知識・技能の伝承 を進めるための実践的な手法の構築が求められている。そ のためには，梅本（1997）が指摘するとおり，工場内での 製品生産とは異なる農業生産の特徵に応じた新たな手法の 構築が必要であり, 農業経営に拈ける知識・技能の内容と 特徵を明らかにした上で, これらの特徵に応じた方策を検 討することが求められる。

第二に，農業分野における知識・技能伝承に関わる既往 研究として, 梅本・山本（2010）による農作業ナレッジの
分類と摘出方法, 藤井ら (2010), 藤井 - 福原 (2011) に よる水稲の代かき，水管理を対象に知識・技能の内容と特 徵を分析した研究などがある。また，知識・技能の伝承方 策にまで踏み込んだ研究としては，梅田（2011）によるコ ンバインの掃除作業を対象にした作業マニュアル作成手法 に関わる研究, 藤井ら（2012）の水稲の育苗作業を対象に した大規模水田作経営に打ける従業員の能力養成のための 情報マネジメントの実施方策に関わる研究, 坂上ら（2012） の企業的農業経営の実践に基づく作業の標準化と人材育成 に関わる研究などがある。このよらに農業分野においても 知識・技能伝承に関わる研究の蓄積が図られつつあるが, これらの研究は主に農作業を対象としたものであり, 本研 究で目的とする従業員の能力養成を図る上では, 作業計画 や作付計画などの広範な領域を対象にした研究の蓄積が求 められる。

第三に, 農業経営情報システムに関わる研究開発も進め られて扣り，近年では，固場地図を活用して作業の計画や 実績などを効率的に管理できる農業経営情報システムの開 発が行われ，代表的なソフトウェアとして吉田ら（2009） による作業計画管理システムなどがあり，生産現場での導 入が図られつつある。 また, 南石（1996）では，農業経営 にかかわる意思決定支援や情報システムの研究開発の意義 と枠組みを技能習得タイムマシンや各種の意思決定支援シ ステムが連携した総合的な営農支援システムの視点から検 討している。そして，2011 年からは農業技術継承执よび 農業人材育成を支援する情報システムの研究開発が農林水 産省委託研究として実施されており，関連する情報システ 厶の開発も進められて扣り, 農作業ノウハウの可視化が可 能になりつつある（南石 2011b, 南石 2011c, Nanseki et al. 2012).

一方, 一般経営学の分野では, 農業分野に先行してナレッ ジマネジメントや知識・技能伝承に関わる多くの研究蓄積 があるが, 代表的な研究として野中ら（1996）によるナレッ ジマネジメント, 森 (2007), 松本（2003）などによる知識・ 技能伝承に関わる研究があり, 本研究で対象とする熟練, ウハウに関連する知識，技能，技術などの概念についても 多くの先行研究がある. 技能に類似する概念として技術が あるが, 森（2005）は, 技能は人間の内なるものとして個 別的・主体的であり流通が困難であること，技術は人間の 外なるものとして客観的・記述的であり, 流通性が高く汎 用性がすぐれている点に相違があるとしたらえで，近年で は，労働現場に抢ける機械やシステムの導入が進む中で, 両者の境界が不明確になり，技術と密接に関連した技能が 要求されていることを指摘している，また，松本（2003） では，技能概念に関わる先行研究のレビューをと扎して， 知識と技能の関係を整理する中で,「知っていること（知）」 を,「内容を知ること」と「方法を知ること」に区分し，「内 容を知ること」が狭義の知識,「方法を知ること」が技能 であるとしている. 本研究で目的とする従業員の能力養成 を図る上では，「内容を知ること」と「方法を知ること」 
の両面からの対応が重要になると考えられることから，松 本（2003）の整理した概念に基づいて，熟練者が有する知 識（「内容を知ること」），技能（「方法を知ること」）を熟 練ノウハウと定義する.

以上の問題意識および研究動向に対する認識から, 本研 究では水稲の作業計画策定業務（春作業，収穫作業）を対 象に熟練ノウハウの内容と特徵を分析するとともに, 当該 業務に関わる従業員の能力養成方策を確立するための指針 を提示することを目的とする，そのために，本研究では滋 賀県内の雇用型法人経営を調査対象に選定し，大規模水田 作経営に和ける作業計画策定の実態を整理する, 次に, 作 業計画の策定に際して熟練者が有する知識・技能を摘出し， その内容と特徵を分析する。 そして, 作業計画策定業務を 担らことが期待される中堅従業員を対象に知識・技能の習 得状況を把握するとともに，習得に向けた問題点を明らか にする. 以上の結果に基づき, 雇用型法人経営に打いて作 業計画策定に関わる従業員の能力養成方策を確立するため の指針を提示する.

なお，作業計画の策定は年間を通して行われるが，収穫 後の秋冬期の本田準備作業, 育苗, 代かき, 田植などの春 作業, 田植後の本田管理作業, 収穫作業など具体的な手順 や内容は，作業の繁閑や性質を反映して相違がある。分析 対象として春作業，収穫作業を選定した理由は，(1) 両作 業ともに水田作経営に打数働ピークを形成しているこ と,（2）春作業では育苗，代かき，田植など複数の作業が 継起的に行われること, 収穫作業では計画判断の結果が収 量・品質に与える影響が大きいことから，研究目的とする
従業員の能力養成を図る上でも重要度・難易度が高い業務 と位置づけられるからである。

\section{方法}

\section{調査対象の概要}

本研究では, 農地流動化に伴い経営の大規模化が進展し ている滋賀県の平坦農業地域に位置する水田作経営の中か ら, 大規模な経営面積にもかかわらず高い収量水準を維持 するなど，経営者が高度な熟練ノウハウを有すると考えら れる雇用型法人経営の 2 事例を調査対象に選定した。両法 人ともに, 近年, 急速に規模拡大が進む中で非農家出身者 などの 20 歳代・30 歳代を中心とした雇用労働力やトラク タ, 田植機, コンバインなど複数の大型高性能機械を導入 することにより対応している（表 1).

これらの経営では, 経営規模の拡大と従業員数の増加に 伴い構成員の職能分化が進展している. 大規模水田作経営 に拈ける経営管理項目と職能の関係を整理した土田 (1997) の区分を参考に調査事例の生産活動に関わる職務分担を示 す (表 2). 両法人の水稲栽培に関わる職務分担は，(1) 作付計画の策定や生産技術体系の選択，資材投入計画，作 業計画の策定など農場全体の生産活動に関わる管理者的職 能を担う「農場管理者」, 担当作業の進捗管理や作業方法 の検討などの担当作業に関わる監督者的職能を担う「作業 責任者」, 作業の実施を担う「作業者」の 3 つ階層に大 別でき，構成員間で複数の職能を同時に担当しながら生産 活動が行われている. この中で管理者的職能は経営者が中

\section{表 1 調査事例の概要}

\begin{tabular}{|c|c|c|c|}
\hline \multicolumn{2}{|c|}{ 項目 } & A 法人 & B 法人 \\
\hline \multicolumn{2}{|c|}{ 労働力 } & 経営者・従業員 17 名 & 経営者・従業員 7 名 \\
\hline \multirow{3}{*}{ 作付面積 } & 水稲 & $135 \mathrm{ha}$ & 45 ha \\
\hline & 小麦 & $15 \mathrm{ha}$ & $23 \mathrm{ha}$ \\
\hline & 大豆 & $7 \mathrm{ha}$ & $26 \mathrm{ha}$ \\
\hline \multirow{3}{*}{ 収量 } & 水稲 & $552 \mathrm{~kg} / 10 \mathrm{a}$ & $530 \mathrm{~kg} / 10 \mathrm{a}$ \\
\hline & 小麦 & $350 \mathrm{~kg} / 10 \mathrm{a}$ & $332 \mathrm{~kg} / 10 \mathrm{a}$ \\
\hline & 大豆 & $215 \mathrm{~kg} / 10 \mathrm{a}$ & $238 \mathrm{~kg} / 10 \mathrm{a}$ \\
\hline \multicolumn{2}{|c|}{ 土壤条件 } & グライ土壌 & グライ土壌 \\
\hline \multicolumn{2}{|c|}{ 水利条件 } & パイプライン方式, 一部オープン水路方式 & オープン水路方式 \\
\hline \multirow{4}{*}{$\begin{array}{l}\text { 主な機械 } \\
\text { 施設装備 }\end{array}$} & トラクタ & $\begin{array}{c}160 \mathrm{ps}(1), \quad 117 \mathrm{ps}(2), 80 \mathrm{ps}(1), 75 \mathrm{ps}(1) \\
65 \mathrm{ps}(1), 60 \mathrm{ps}(2), \quad 55 \mathrm{ps}(1), 42 \mathrm{ps} \text { (1) }\end{array}$ & $80 \mathrm{ps}(1), 65 \mathrm{ps}(1), 60 \mathrm{ps}(2), 42 \mathrm{ps}$ (1) \\
\hline & 田植機 & 8 条 (5) & 8 条 (1) \\
\hline & コンバイン & 6 条 (4), 7 条 (1) & 6 条 (2) \\
\hline & 乾燥機 & 491 石（7） & 544 石（8） \\
\hline
\end{tabular}

注：経営者への聞き取りにより作成．主な機械施設装備（）内は台数を表す。 
表 2 職能分化と担当（水稲作）

\begin{tabular}{|c|c|c|c|c|c|c|c|}
\hline \multirow{3}{*}{ 区分 } & \multirow{3}{*}{ 内容 } & \multicolumn{3}{|c|}{ A 法人 } & \multicolumn{3}{|c|}{ B 法人 } \\
\hline & & 作業者 & 作業責任者 & 農場管理者 & 作業者 & 作業責任者 & 農場管理者 \\
\hline & & 従業員 & 中堅従業員 & 経営者・専務 & 従業員 & 中堅従業員 & 経営者 \\
\hline \multirow{4}{*}{ 管理者 } & $\begin{array}{l}\text { 作付計画の策定 : 栽培方法・品種・作 } \\
\text { 型単位の作付面積と圃場配置の決定 }\end{array}$ & & & (a) & & & () \\
\hline & $\begin{array}{l}\text { 生産技術体系の選択 : 栽培方法および } \\
\text { 作業技術体系の決定 }\end{array}$ & & & (a) & & & () \\
\hline & $\begin{array}{l}\text { 資材投入計画の策定 : 資材の選択と投 } \\
\text { 入量の決定 }\end{array}$ & & & () & & & () \\
\hline & $\begin{array}{l}\text { 作業計画の策定 : 農場全体の作業の進 } \\
\text { 渉管理および作業内容の決定 }\end{array}$ & & $\triangle$ & (a) & & $\triangle$ & (a) \\
\hline \multirow{2}{*}{ 監督者 } & $\begin{array}{l}\text { 作業管理 : 作業の実績把握および作業 } \\
\text { 方法の改善 }\end{array}$ & & (0) & $\bigcirc$ & & (a) & O \\
\hline & 作業準備 : 作業の事前準備, 段取り & $\bigcirc$ & () & $\bigcirc$ & $\bigcirc$ & () & $\bigcirc$ \\
\hline 作業者 & 作業の実施 & (2) & (a) & $\triangle$ & (a) & (a) & 0 \\
\hline
\end{tabular}

注：経営者への聞き取りにより作成. (○) : 主担当, $\bigcirc$ : 担当, $\triangle$ : 部分的に担当を表す.

心的役割を担っており，今後の世代交代に向けて管理者的 職能を担ら人材育成が従業員の能力養成上の重要な課題と なっている.

本研究で対象とする作業計画の策定は, 管理者的職能の 中でも作業との関連性が深く, 監督者的職能を経験した従 業員が管理者的職能を担当する上で, 最初に権限委譲が図 られる業務として位置づけられる。このため，近年では， 両法人ともに作業計画の策定業務については，作業経験と コミュニケーション能力などを考慮して選定した中堅従業 員 (A 法人:農業従事経験 4 年, B 法人: 農業従事経験 6 年) と経営者が相談しながら実施する体制に移行してきてい る。な敃，作業計画策定に関わる教育指導の実施状況は， 両法人ともに経営者が中堅従業員との対話をとおして計画 策定のポイントや注意点を口頭で説明することによる対応 が行われている程度である。

\section{調査方法}

本研究では, 調査対象に抢ける経営者, 従業員への聞き 取りなどを中心とした事例分析に基づく調査方法を採用し た. その理由は, 研究目的とする雇用型法人経営に报ける 従業員の能力養成方策を検討する上では聞き取りなぞによ る事例分析を通して, 熟練, ウハウの内容と特徴をさまざ まな側面から具体的に検討することが重要であると考えら れるからである。

調査は以下の方法により実施した。 まず，作業計画策定 の実態を把握するために, 各法人経営者への聞き取りを通 して作業計画策定の手順と内容を整理した. 次に, 経営者 が作業計画策定に際して有する知識・技能を摘出した。知 識・技能の摘出は, 春作業では「育苗」から「本田除草剂
散布」作業 (A 法人 11 作業, B 法人 10 作業), 収穫作業 では「落水」,「収穫」,「乾燥調製」作業を対象に, (1) 滋 賀県稲作技術指導指針に記載されている作業の計画策定に 関わるポイント，留意点等を整理した一覧表を提示しなが ら, 計画策定の基本的方法やポイント等の聞き取りを行ら, （2）作業期間中に作業実績を提示しながら, 作業計画判断 の理由について聞き取りを行う，（3）得られた発話データ の内容を読み取り, 整理して再度聞き取りを行うといら手 順で実施した。

次に，発話データを意味的にひとまとまりになるよら区 切り, その内容を読又取り, 梅本・山本（2010）の定義を 参考に知識・技能の種類を判定するとともに，その内容と 特徵を分析した，梅本・山本（2010）では，固場内機械作 業を対象に農作業に関わる知識・技能を継承の観点から一 般的知識, 経営固有知識, 運動系技能, 感覚系技能, 知的 管理系技能の 5 種類に分類している．梅本・山本（2010） の定義を援用した理由は, 本研究で目的とする従業員の能 力養成方策を検討する上では, 知識・技能の内容を継承の 観点から分類して検討することが重要と考兄られるからで ある。なお，梅本・山本（2010）では，圃場内機械作業に 扣ける作業の段取り, 作業中の作業方法の選択など,「作 業の手順・方法を計画して修正する技能」を知的管理系技 能と定義しているが，本研究では作業計画を対象とするこ とから, その中心的内容と考えられる「作業適期, 優先順 位, 順序, 方法を計画して修正する技能」を知的管理系技 能と定義する（図 1).

そして，今後の作業計画策定業務を担らことが期待され る中堅従業員への聞き取りにより, 知識・技能の習得状況 および習得に向けた問題点を把握するとともに, 雇用型法 


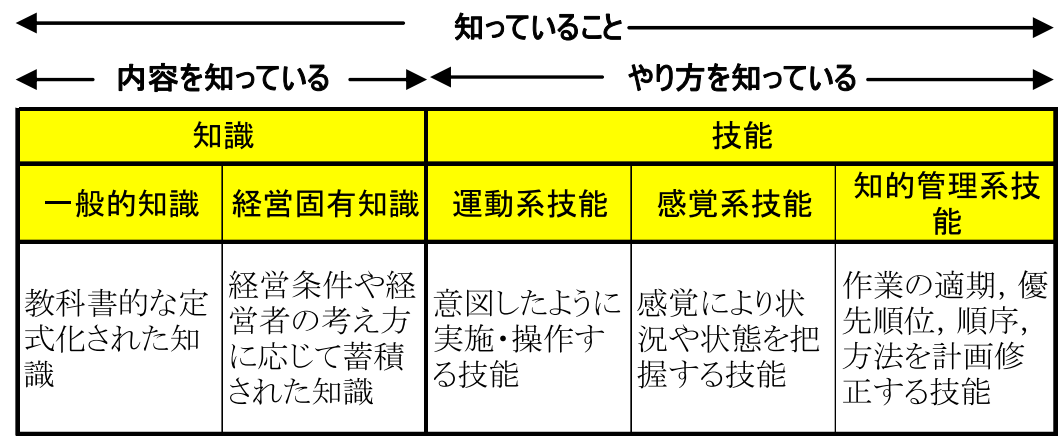

図 1 熟練ノウハウの種類と定義

注：1）本研究では上記分類に基づく知識・技能を熟練ノウハウと定義する.

2）山本・梅本（2010）を修正加工

表 3 春作業計画策定の手順と内容

\begin{tabular}{|c|c|c|c|c|}
\hline 手順 & 検討時期 & 検討内容 & 考慮する主な要因 & 決定内容 \\
\hline $\begin{array}{l}\text { 田植計画の } \\
\text { 決定 }\end{array}$ & 12 月～ 2 月頃 & $\begin{array}{l}\text { 作付予定面積に基づき栽培方 } \\
\text { 法・品種毎の戒場配置, 田植日 } \\
\text { を決定する（育苗播種計画との } \\
\text { 調整を図りながら必要に応じて } \\
\text { 修正） }\end{array}$ & $\begin{array}{l}\text { 圃場特性 (土質, 前作), 移動 } \\
\text { 条件 (移動距離, 地区別圃場面 } \\
\text { 積), 地域条件 (水利条件, 集 } \\
\text { 落風土), 機械処理能力 (田植機) } \\
\text { など }\end{array}$ & $\begin{array}{l}\text { 育苗播種ロットを基本単位に圑 } \\
\text { 場配置および田植開始日・終了 } \\
\text { 日を決定 }\end{array}$ \\
\hline $\begin{array}{l}\text { 育苗播種計画の } \\
\text { 決定 }\end{array}$ & 12 月～ 2 月頃 & $\begin{array}{l}\text { 田植計画に基づき育苗播種計画 } \\
\text { (播種日・品種・播種枚数) を } \\
\text { 決定する（田植計画との調整を } \\
\text { 図りながら必要に応じて修正） }\end{array}$ & $\begin{array}{l}\text { 機械施設処理能力（田植機・育 } \\
\text { 苗ハウス）, 時期別育苗所要日 } \\
\text { 数など }\end{array}$ & $\begin{array}{l}\text { 播種日・品種・播種枚数を日単 } \\
\text { 位に設定 }\end{array}$ \\
\hline $\begin{array}{l}\text { 全体計画の } \\
\text { 決定 }\end{array}$ & 3 月頃 & $\begin{array}{l}\text { 育苗播種計画（育苗作業)，田 } \\
\text { 植計画（本田作業）を基点に, } \\
\text { 前後工程の基本スケジュールを } \\
\text { 決定する }\end{array}$ & $\begin{array}{l}\text { 育苗作業 : 時期別・作業工程別 } \\
\text { 所要日数, 品種特性など, 本田 } \\
\text { 作業 : 作業適期, 必要人員, 機 } \\
\text { 械施設処理能力など }\end{array}$ & $\begin{array}{l}\text { 本田作業: 作業毎に作業時期(開 } \\
\text { 始時期, 終了時期) を設定, 育 } \\
\text { 苗作業 : 育苗播種ロット単位に } \\
\text { 作業日を設定 }\end{array}$ \\
\hline 作業の決定 & 作業期間中 & $\begin{array}{l}\text { 作業計画を段階的に具体化し, } \\
\text { 当日の作業内容を決定する }\end{array}$ & $\begin{array}{l}\text { 作業実績 (作業の進渉状況, 前 } \\
\text { 後工程間の作業間隔日数), 気 } \\
\text { 象条件 (降雨, 風, 気温), 生 } \\
\text { 育状況 (苗質, 活着), 圃場の } \\
\text { 状態なと }\end{array}$ & $\begin{array}{l}\text { 作業内容, 優先順位，順序など } \\
\text { を設定 }\end{array}$ \\
\hline
\end{tabular}

注 : 熟練者への聞き取り調査により作成

人経営に打ける作業計画策定に関わる従業員の能力養成方 策について検討した.

\section{結果と考察}

\section{春作業計画策定の手順と内容}

春作業の計画策定は，両法人ともに「田植計画の決定」, 「育苗播種計画の決定」,「全体計画の決定」,「作業の決定」 の4つの手順に大別できる（表 3).

「田植計画の決定」では, 販売戦略や作期分散などを考 慮して別途検討した栽培方法・品種・作型単位の作付予定 面積に基づき, 具体的な田植計画（國場配置, 田植日）を 決定する，ここでは，（1）固場特性（土質，前作），(2） 移動条件（移動距離, 地区別戋場面積），(3）地域条件（水 利条件, 集落風土), (4) 機械処理能力（田植機）などを
考慮して決定している.

「育苗播種計画の決定」では, 田植計画（田植予定日, 面積）に基づき育苗播種計画を決定する。ここでは，機械 施設処理能力 (育苗八ウス, 田植機), 時期別育苗所要日 数などを考慮して, 田植計画との調整を図りながら播種日・ 品種・播種枚数（以下，育苗播種口ットといら）を決定す る. そして, 最終的な田植計画は, 育苗播種ロットを基本 単位として固場配置および田植の始期と終期（3〜5 日程 度）を明示する。ただし，A 法人では 2012 年度から作業 の進捗管理を徹底するため日単位での計画策定に着手して いる。 また，育苗播種計画では，両法人ともに日単位で播 種日を設定している.

「全体計画の決定」では，育苗作業の基軸となる育苗播 種計画，本田作業の基軸となる田植計画に基づき前後工程 の基本スケジュールを決定する, 具体的には, 育苗作業で 
表 4 収穫作業策定の手順と内容

\begin{tabular}{|c|c|c|c|c|c|}
\hline & 手順 & 検討時期 & 検討内容 & 考慮する主な要因 & 決定内容 \\
\hline \multirow{2}{*}{$\begin{array}{l}\text { 收 } \\
\text { 檴 } \\
\text { 順 } \\
\text { 蓣 } \\
\text { 決 } \\
\text { 定 }\end{array}$} & $\begin{array}{c}\text { 收穫適期の } \\
\text { 予測 }\end{array}$ & \multirow{2}{*}{$\begin{array}{l}\text { 収穫が予想される } 7 \text { } \\
10 \text { 日前頃から本格的 } \\
\text { に検討を開始 }\end{array}$} & $\begin{array}{l}\text { 育苗播種ロット・地区を基 } \\
\text { 本単位に収穫適期を予測す } \\
\text { るとともに落水時期を決定 } \\
\text { する }\end{array}$ & $\begin{array}{l}\text { 成熟状態（籾の黄化率, 葉 } \\
\text { 色, 倒伏, 生育么ラ), 圃 } \\
\text { 場条件（田面の乾き具合, } \\
\text { 土質), 気象条件（気温, } \\
\text { 日照, 降雨）など }\end{array}$ & \multirow{2}{*}{$\begin{array}{l}\text { 育苗播種ロット・地区を基 } \\
\text { 本単位に概ねの収穫適期, } \\
\text { 優先順位を決定 }\end{array}$} \\
\hline & $\begin{array}{c}\text { 優先順位の } \\
\text { 決定 }\end{array}$ & & $\begin{array}{l}\text { 育苗播種ロット・地区を基 } \\
\text { 本単位に収穫の優先順位を } \\
\text { 決定する }\end{array}$ & $\begin{array}{l}\text { 収穫適期（成熟状態, 圃場 } \\
\text { 条件), 栽培方針・品種特性, } \\
\text { 気象条件 (気温, 日照, 降 } \\
\text { 雨), 作業条件（機械施設 } \\
\text { 処理能力, 作業の進渉状況) } \\
\text { など }\end{array}$ & \\
\hline \multicolumn{2}{|c|}{ 收穫作業の決定 } & 作業前日～当日 & $\begin{array}{l}\text { 当日の収穫作業計画を決定 } \\
\text { する }\end{array}$ & $\begin{array}{l}\text { 収穫適期, 作業条件（乾燥 } \\
\text { 調製施設の稼動状況, 作業 } \\
\text { の進渉状況), 気象条件 (気 } \\
\text { 温, 日照, 降雨, 風) など }\end{array}$ & $\begin{array}{l}\text { 当日の作業実施圃場 (必要 } \\
\text { に応じて順序を指定), 作 } \\
\text { 業開始時間, コンバイン投 } \\
\text { 入台数を決定 }\end{array}$ \\
\hline
\end{tabular}

注 : 熟練者への聞き取り調査により作成

は，育苗播種計画に基づき浸種，催芽，出芽などの時期別・ 作業工程別所要日数, 品種特性なぞを考慮して, 育苗作業 全体の基本スケジュールを決定する，本田作業では，田植 計画に基づき代かき,荒起こしなぞの作業適期や必要人員, 機械施設処理能力などを考慮して，本田作業の基本スケ ジュールを決定する。これらの計画は, 両法人ともに屋内 作業中心で計画的に作業を実施できる育苗作業を除き，作 業の開始時期, 終了時期の目安を設定している程度であり, 日単位などでの詳細な計画は策定していない，なお，上記 の手順は, 両法人ともに冬期から検討を開始し, 春作業が 本格化する 3 月上旬を目処に決定している.

「作業の決定」では, 気象や生育, 圃場や作業の状況に 応じて作業計画を具体的に決定していく，具体的には，全 体計画に基づきながら（1）作業実績（作業の進渉状況， 前後工程間の作業間隔日数)，(2) 気象条件（降雨，風， 気温),（3）生育状況（苗質，活着)，（4）國場の状態など を考慮して，週間単位から日単位へと作業計画を具体化し ている。な招，作業が継起的に行わ孙る育苗作業（種子予 措, 浸種, 催芽, 播種) では育苗播種ロット，本田作業（荒 代，代かき，田植，本田除草剂散布）では育苗播種ロット を地区毎に分割（以下，育苗播種ロット・地区といら）乙 た上で作業の進捗管理を行いながら作業の実施判断を行っ ている.

以上のと抢り，春作業計画の策定は，作業計画の基点と なる「田植計画」，「育苗播種計画」について月日を絞り込 んだ具体的な作業計画を設定するとともに，これらの計画 飞基づき前後工程を含めた作業の基本計画（開始時期，終 了時期）を決定している。 そして, 生育状況や固場条件, 気象条件などの状況に応じた変更を繰り返しながら, 週単 位から日単位へと作業計画を具体化していく。李た，春作 業計画の策定に際しては，田植計画・育苗作業では育苗播 種ロット，本田作業では育苗播種ロット・地区単位に作業
の計画策定と進渉管理を行っている.

\section{収穫作業計画策定の手順と内容}

収穫作業の計画は, 両法人ともに「収檴順序の決定」, 「収 穫作業の決定」の 2 つの手順に大別できる（表 4).

「收穫順序の決定」は，「收穫適期の予測」と「收穫優先 順位の決定」に大別できる。「収穫適期の予測」では, 育 苗播種ロット・地区単位で概放の収穫適期を予測するとと もに, 落水時期を決定する。具体的には, 作付計画策定時 点での予想収穫時期（概衫半旬単位）を基本にして，当該 年の成熟状況 (籾の黄化率, 葉色, 倒伏, 生育么ラ）や戋 場条件（田面の乾き具合）の観察に基づき収穫適期を予測 するとともに, 気象条件（気温, 日照, 降雨）や戋場条件（土 質）などを勘案しながら落水のタイミングを判断する。そ して, 「収穫優先順位の決定」では, 収穫適期の予測結果 をもとに育苗播種ロット・地区を基本単位に収穫の優先順 位を決定する。具体的には, 収穫適期（成熟状況, 圃場条件) や栽培方針掞よび品種特性，気象条件（気温，日照，降雨）, 作業条件（機械施設処理能力，作業の進渉状況）なぞを考 慮した上で決定する。「収穫順序の決定」は, 予測した収 穫適期の概水 $7 \sim 10$ 日前頃から本格的に実施している.

次に, 「收穫作業の決定」では, 收穫作業を行ら戋場抒 よび作業順序，作業開始時間，収穫予定面積などを決定す る. ここでは, 作業前日から当日朝にかけて収穫適期の状 態を最終確認した上で，作業条件（乾燥調製施設の稼働状 況), 気象条件 (気温, 日照, 降雨, 風) などを考慮して 当日の収穫作業の内容（作業開始時間，作業実施圃場，コ ンバイン投入台数など）を最終決定する.

以上のと招り，収穫作業の計画策定は，作付計画策定時 での予想收穫時期を基点として, 当該年度に和ける生育状 況や気象条件などの状況に応じた変更を繰り返しながら段 階的に作業計画を具体化していく。そして, 収穫作業計画 
表 5 知識・技能の種類と構成

\begin{tabular}{|c|c|c|c|c|c|c|c|c|c|}
\hline & & \multirow{3}{*}{ 区分 } & & \multirow{3}{*}{ 合計 } & \multicolumn{5}{|c|}{ 種類別の構成 } \\
\hline & & & & & \multicolumn{2}{|c|}{ 知識 } & \multicolumn{3}{|c|}{ 技能 } \\
\hline & & & & & 一般的知識 & $\begin{array}{c}\text { 経営固有 } \\
\text { 知識 }\end{array}$ & 運動系技能 & 感覚系技能 & $\begin{array}{c}\text { 知的管理系 } \\
\text { 技能 }\end{array}$ \\
\hline \multirow{8}{*}{ 作業計画 } & \multirow{4}{*}{ 春作業 } & \multirow{2}{*}{ A 法人 } & 知識・技能数 & 83 & 10 & 61 & 0 & 0 & 12 \\
\hline & & & 構成比 & 100 & 12.0 & 73.5 & 0.0 & 0.0 & 14.5 \\
\hline & & \multirow{2}{*}{ B 法人 } & 知識 - 技能数 & 78 & 8 & 59 & 0 & 0 & 11 \\
\hline & & & 構成比 & 100 & 10.3 & 75.6 & 0.0 & 0.0 & 14.1 \\
\hline & \multirow{4}{*}{ 収穫作業 } & \multirow{2}{*}{ A 法人 } & 知識・技能数 & 47 & 10 & 26 & 0 & 2 & 9 \\
\hline & & & 構成比 & 96 & 21.3 & 55.3 & 0.0 & 0.0 & 19.1 \\
\hline & & \multirow{2}{*}{ B 法人 } & 知識・技能数 & 54 & 12 & 30 & 0 & 3 & 9 \\
\hline & & & 構成比 & 100 & 22.2 & 55.6 & 0.0 & 5.6 & 16.7 \\
\hline \multirow{4}{*}{ 農作業 } & \multirow{4}{*}{ 代かき } & \multirow{2}{*}{ A 法人 } & 知識・技能数 & 86 & 3 & 50 & 10 & 12 & 11 \\
\hline & & & 構成比 & 100 & 3.5 & 58.1 & 11.6 & 14.0 & 12.8 \\
\hline & & \multirow{2}{*}{ B 法人 } & 知識・技能数 & 111 & 9 & 71 & 14 & 6 & 11 \\
\hline & & & 構成比 & 100 & 8.1 & 64.0 & 12.6 & 5.4 & 9.9 \\
\hline
\end{tabular}

注：代かきの技能・知識は藤井ら（2010）の調査結果を再掲.なお，運動系技能は作業計画では確認できなかった.

の策定に際しては育苗播種ロット・地区を基本単位として 収穫適期の予測や収穫優先順位を決定するなどの重要な判 断が行われている.

\section{大規模水田作経営における作業計画策定の特徵}

以上の結果を踏まえると, 大規模水田作経営に打ける作 業計画策定の特徵として以下の点が指摘できる.

第一に，作業工程や作物の生育ステージに沿って継起的 に作業を進めていく農作業では, 計画策定の起点となる計 画（春作業：田植，育苗播種，収穫作業：作付計画）に基 ついて作業計画を段階的に策定していくことが特徴であ り, これらの計画では他作業に比べて月日を絞り込んだ詳 細な計画を策定している。

第二に, 具体的な作業計画は, 気象や生育, 圃場, 作業 の進渉状況などの状況変化に応じて作業の計画的実施が困 難な大規模水田作経営の性質を反映して, 变化する状況に 応じた判断を繰り返しながら，週単位から日単位へと段階 的に具体化していくことが特徵である.

第三に，作業計画の具体化に際しては，圃場筆数が多い 大規模水田作経営では, 作業の進渉管理や生育状況の把握, 作業実施のタイミング判断などを育苗播種ロット扎よび育 苗播種ロット・地区を基本単位に実施していることが特徵 である。

\section{作業計画に関わる知識・技能の種類と構成}

熟練者への聞き取りにより抽出した知識・技能を整理し て, 梅本・山本（2010）らの定義を参考に知識・技能の種 類と構成を分析したところ以下のと扤りとなった（表 5).

作業計画に関わる知識・技能の数は, 両事例とも春作業 では 80 前後, 収穫作業では 50 前後となるなどかなり多い. 藤井ら (2010) が本研究と同じ調査事例で実施した農作業(代 かき）に扔ける調査結果と比較したところ，（1）知識では, 農作業と同様に経営固有知識（経営条件や経営者の考方方 などに応じて蓄積された知識）の占める割合が高くその数 も多いこと，（2）技能では，作業計画策定業務の性質を反 映して知的管理系技能の占める割合が高いことを確認した。

また，これらの知識を適用場面別に整理したところ，農 作業と同様に多様な条件に応じて使い分ける内容が多いこ とが特徴であり, 具体的内容は「作業条件」(機械施設装備, 作業の進渉状況, 作業の競合など), 「圃場条件」（固場特性， 固場の状況など)，「栽培条件」（品種・作型・栽培方法, 生育状況など), 「気象条件」(降雨, 強風, 低温なぞ), 「地 域条件」（集落の風土，水利，耕作者など）により構成さ れる（表 6）。そして，要因別には春作業，収穫作業とも に「栽培条件」に応じて使い分ける内容が最も多いが，作 業性（作業能率・作業精度）が圃場条件の影響を受けやす い春作業では，「圃場条件」に応じて使い分ける内容の割 合が高いのに対して，収量・品質のロスを低減するために 適期収穫が重要となる収穫作業では，「栽培条件」に応じ 
表 6 知識の適用場面別構成

\begin{tabular}{|c|c|c|c|c|c|c|c|c|c|}
\hline & \multirow{2}{*}{ 区分 } & & \multirow{2}{*}{ 知識数 } & \multicolumn{6}{|c|}{ 適用場面に応じた構成 } \\
\hline & & & & 共通 & 作業条件 & 圃場条件 & 栽培条件 & 気象条件 & 地域条件 \\
\hline \multirow{4}{*}{ 春作業 } & \multirow{2}{*}{ A 法人 } & 知識数 & 71 & 17 & 5 & 17 & 18 & 10 & 4 \\
\hline & & 構成比 & 100 & 23.9 & 7.0 & 23.9 & 25.4 & 14.1 & 5.6 \\
\hline & \multirow{2}{*}{ B 法人 } & 知識数 & 67 & 11 & 6 & 17 & 18 & 9 & 6 \\
\hline & & 構成比 & 100 & 16.4 & 9.0 & 25.4 & 26.9 & 13.4 & 9.0 \\
\hline \multirow{4}{*}{ 收穫作業 } & \multirow{2}{*}{$\mathrm{A}$ 法人 } & 知識数 & 36 & 9 & 2 & 5 & 15 & 4 & 1 \\
\hline & & 構成比 & 100 & 25.0 & 5.6 & 13.9 & 41.7 & 11.1 & 2.8 \\
\hline & \multirow{2}{*}{ B 法人 } & 知識数 & 42 & 11 & 3 & 3 & 16 & 3 & 6 \\
\hline & & 構成比 & 100 & 26.2 & 7.1 & 7.1 & 38.1 & 7.1 & 14.3 \\
\hline
\end{tabular}

注 : 表中の数值は適用場面に応じて使い分けることが確認された知識数・構成比を表す。共通は条件に関わらず用いる知識を表す。

表 7 知識 - 技能の内容

\begin{tabular}{|c|c|c|c|}
\hline 技能 & 知識の種類 & 区分 & 具体的内容 \\
\hline \multirow{2}{*}{ 一般的知識 } & \multirow{2}{*}{$\begin{array}{l}\text { 教科書的な定型化さ } \\
\text { れた知識 }\end{array}$} & 春作業 & $\begin{array}{l}\text { 畦畔除草剤散布 : 除草剂散布後半日以内に降雨が予想される場合は, 畔畔除草剂 } \\
\text { の散布作業は行わない }\end{array}$ \\
\hline & & 収穫作業 & $\begin{array}{l}\text { もち米収穫適期 : もち米の収穫適期は黄化率 90\%を目安として, 籾の黄化率を } \\
\text { しっかりと観察して, 早刈り, 刏り遅れによる品質低下を防ぐ }\end{array}$ \\
\hline \multirow[b]{2}{*}{$\begin{array}{c}\text { 経営固有 } \\
\text { 知識 }\end{array}$} & \multirow{2}{*}{$\begin{array}{l}\text { 経営条件や経営者の } \\
\text { 考え方に応じて蓄積 } \\
\text { された知識 }\end{array}$} & 春作業 & $\begin{array}{l}\text { 集落の風土 : A 集落は田植え時期を遅くすると, 周囲の耕作者から嫌がられるの } \\
\text { で5 月中旬までに田植えを終わらせる }\end{array}$ \\
\hline & & 収穫作業 & $\begin{array}{l}\text { 収穫適期: 作業の進渉状況などによりどらしても早杊りしないと行けない場合は, } \\
\text { 品質重視の品種は籾黄化率が } 70 \% \text { 程度, 収量重視の品種は籾黄化率が } 85 \% \text { を収 } \\
\text { 穫適期の早限の目安とする A 地区は, 同じ時期に田植えしても他の地区に比べ } \\
\text { て収穫が } 3 \sim 4 \text { 日程度遅くなる }\end{array}$ \\
\hline 感覚系技能 & $\begin{array}{l}\text { 感覚により状況や状 } \\
\text { 態を把握する技能 }\end{array}$ & 収穫作業 & $\begin{array}{l}\text { 黄化率の把握 : 複数の株を両手で束ねて, 黄化している籾の割合を達観で観察し } \\
\text { て把握する }\end{array}$ \\
\hline \multirow{2}{*}{$\begin{array}{c}\text { 知的管理系 } \\
\text { 技能 }\end{array}$} & \multirow{2}{*}{$\begin{array}{l}\text { 手順・方法を計画し } \\
\text { 修正する技能 }\end{array}$} & 春作業 & $\begin{array}{l}\text { 作業の実施判断：（1）額縁堀（代かきの前工程）の進渉状況，(2) 代かきの進渉 } \\
\text { 状況，(2) 圃場条件（土質，前作など）に応じた作業間隔日数を考慮して作業の } \\
\text { ペースを調整する }\end{array}$ \\
\hline & & 收穫作業 & $\begin{array}{l}\text { 収穫作業開始のタイミングの判断：(1）稲の成熟状況，（2）作業の進渉状況，（3） } \\
\text { 気象条件，（4）作業の処理能力，（5）栽培方針・品種特性などを考慮して収穫作 } \\
\text { 業開始のタイミングを判断する }\end{array}$ \\
\hline
\end{tabular}

注: 熟練者への聞き取り調査で得られた発話データの内容を要約したものである.なお，今回の調査では運動系技能は確認されなかった.

て使い分ける内容の割合が高いなぞ，作業の性質を反映し て重要な要因には相違があることが確認できる.

\section{作業計画における知識・技能の内容}

次に, 作業計画に括ける知識・技能の具体的内容を表 7 に示す。知識は, 一般的知識では「畦畔除草剤は, 散布後 半日以内に降雨が予想される場合には畦畔除草剂を散布し ない」,「もち米の収穫適期は黄化率 90\%を目安として, 籾の状態をしっかりと観察して，早杊り・刈り遅れによる
品質低下を防ぐ」など，作業計画を策定する上での基本的 内容が多い。一方, 経営固有知識は, 梅本・山本 (2010) の定義では, 経営条件や経営者の考え方に応じて蓄積され た知識としているが，その内容を固有性に着目して分類し たところ，（1）一般的な知識や考方方を, 経営条件や経営 者の考方方を反映して応用した知識 (以下, 応用型といら), （2）経営方針や経営の特徵を反映して経営内で独自に蓄積 された知識（以下，固有型）に大別できた（表 8).

「応用型」の経営固有知識は, 例えば,一般的知識では「籾 
表 8 経営固有知識の具体的内容

\begin{tabular}{|c|c|c|c|c|}
\hline \multirow{2}{*}{ 区分 } & \multirow{2}{*}{ 一般的知識 - 考光方 } & \multicolumn{2}{|c|}{ 経営固有知識 } & \multirow{2}{*}{ 備考 } \\
\hline & & A 法人 & B 法人 & \\
\hline \multirow{2}{*}{ 応用型 } & $\begin{array}{l}\text { 籾黄化率が } 85 \sim 90 \% \text { の } \\
\text { 状態で適期収穫を行 } 5 \\
\text { (滋賀県稲作技術指導 } \\
\text { 指針) }\end{array}$ & $\begin{array}{l}\text { 事情により早刈りしないと行け } \\
\text { ない場合は, 収穫適期の早限は } \\
\text { 品質重視の品種は籾黄化率 } \\
70 \% \text { 程度, 収量重視の品種籾黄 } \\
\text { 化率が } 85 \% \text { 目安とする }\end{array}$ & $\begin{array}{l}\text { 事情により早㺫りしないといけ } \\
\text { ない場合は, 収穫適期の早限は } \\
\text { 籾黄化率 75\%\%程度, 適期は籾 } \\
\text { 黄化率 } 80 \sim 85 \% \text { 程度を目安と } \\
\text { する }\end{array}$ & $\begin{array}{l}\text { 栽培方針や作業条件を反映して } \\
\text { 收檴適期の目安となる籾黄化率 } \\
\text { を変更した知識 }\end{array}$ \\
\hline & $\begin{array}{l}\text { 周囲の耕作者・地域住民 } \\
\text { に配慮して農作業を行ら }\end{array}$ & $\begin{array}{l}\text { A 集落は田植え時期を遅くする } \\
\text { と, 周囲の耕作者から嫌がられ } \\
\text { るので } 5 \text { 月中旬までに田植えを } \\
\text { 終わらせる }\end{array}$ & $\begin{array}{l}\text { 民家近くの稲刈りはできる限り } \\
\text { 在宅者が少ない日中に行う }\end{array}$ & $\begin{array}{l}\text { 周囲の耕作者・地域住民に配慮 } \\
\text { 乙て農作業を行 } う と ら \text { 水田作 } \\
\text { 経営の一般的な考え方を, 経営 } \\
\text { 方針や経営条件に応じて具体化 } \\
\text { された知識 }\end{array}$ \\
\hline \multirow{2}{*}{ 固有型 } & - & - & $\begin{array}{l}\text { 畦抜きにより大区画化した固場 } \\
\text { の代かきで土を } 10 \mathrm{~cm} \text { 以上動か } \\
\text { した場合, 田植えまでの作業間 } \\
\text { 隔を } 4 \text { 日程度空ける（土と水を } \\
\text { しっかりとなじませる必要があ } \\
\text { るので） }\end{array}$ & $\begin{array}{l}\text { 作業効率化のために農地の面的 } \\
\text { 集積と國場の大区画化を積極的 } \\
\text { に進める経営方針に基づき独自 } \\
\text { に蓄積された知識 }\end{array}$ \\
\hline & - & - & $\begin{array}{l}\text { 圑場毎に収穫時期の葉色, 穂色, } \\
\text { 生育ムラ, 病害虫の被害状況な } \\
\text { ぞを観察する（品質を区分して } \\
\text { 収穫し安定した品質の米を提供 } \\
\text { するため) }\end{array}$ & $\begin{array}{l}\text { 安定した品質の農産物供給を徹 } \\
\text { 底する経営方針に基づき独自に } \\
\text { 蓄積された知識 }\end{array}$ \\
\hline
\end{tabular}

注 : 熟練者への聞き取り調査より作成.

黄化率 $85 \sim 90 \%$ の状態を収穫適期とする」（滋賀県稲作 技術指導指針）に対して，「事情により早刈りしないとい けない場合は, 収穫適期の早限は品質重視の品種では籾黄 化率 70\%, 収量重視の品種では籾黄化率 85\%の状態」（A 法人)，「事情により早㺫りしないといけない場合は，収穫 適期の早限は籾黄化率 75\%，収穫適期は 80〜85\%程度を 目安とする」（B 法人）など，栽培方針や経営条件を考慮 して一般的知識と異なる目安が設定されている。 また，「A 集落は田植時期を遅くすると周囲の耕作者から嫌がられる ので5月中旬までに田植えを終わらせる」(A 法人)，「民 家近くの稲㺫りはできる限り在宅者が少ない日中に行ら」 (B 法人) などの知識は, 水田作経営の一般的考え方とし て知られている「近隣耕作者, 地域住民に配慮して農作業 を行う」ことを経営条件（集落の風土）, 経営者の考方方 を反映して具体化したものである。このように応用型の経 営固有知識では一般的な知識や考方方を, 経営条件や経営 者の考方方を反映して応用した知識として捉えられる.

一方，「固有型」の経営固有知識は，例えば「畦抜きに より大区画化した圃場の代かきで土を $10 \mathrm{~cm}$ 以上動かした 場合, 代かき後田植えまで作業間隔を4 日程度空ける」では, 作業の効率化のために農地の集積と圃場の大区画化を積極 的に進めている A 法人の経営方針を反映して蓄積された知 識であり, 同様の知識は B 法人では確認されていない。 た, 「圃場毎に収穫時期の葉色, 穂色, 生育么ラ, 病害虫 の被害状況なぞを観察する」では，安定した品質の米の供 給を徹底する $\mathrm{B}$ 法人の経営方針を反映して独自に蓄積され
た知識であり，A 法人では確認されていない。このように 固有型の経営固有知識は，経営方針に応じて経営内で独自 に蓄積された経営固有性の高い知識として捉えられる.

次に，技能では感覚系技能，知的管理系技能が確認され た. 感覚系技能は, 「複数の株を両手で束ね, 黄化してい る籾の割合を達観で観察して把握する」など，視覚により 状況を把握する技能でありその数は少ない，一方，知的管 理系技能では，「(1) 額縁堀・代かきの作業進渉状沉，（2） 圃場条件（土質，前作など）に応じた作業間隔日数を考慮 して作業のペースを調整する」，「(1) 稲の成熟状沉，（2） 作業の進渉状況，（3）気象条件，（4）作業の処理能力，(5) 栽培方針・品種特性などを考慮して収穫適期のタイミング を判断する」など，複数の要因を考慮して総合的に判断す る内容であることが特徵であり，作業計画に関わる中心的 技能であるといえる。 そして，知的管理系技能は，言語に より表現するだけでは非熟練者に伝承することは困難であ るため, 知的管理系技能は, 作業計画策定に関わる従業員 の能力養成を図る上でも重要度が高い技能と考えられる. そこで，以下では作業計画策定に関わる中心的な技能であ る知的管理系技能に焦点を当てて，その内容と特徴につい て検討する.

\section{知的管理系技能の内容と特徵}

知的管理系技能の具体的内容を表 9 に示す。知的管理系 技能を判断の性質に応じて分類したところ，（1）作業実績 や作業条件なぞの確定されたデータに基づき不確実性が小 
表 9 知的管理系技能と具体例と考慮する要因数

\begin{tabular}{|c|c|c|c|c|c|c|c|c|}
\hline \multirow[b]{2}{*}{$\begin{array}{l}\text { 分 } \\
\text { 類 }\end{array}$} & \multirow[b]{2}{*}{ 判断の性質 } & \multirow[b]{2}{*}{ 区分 } & \multirow[b]{2}{*}{ 発話内容 } & \multirow[b]{2}{*}{ 知的管理系技能 } & \multicolumn{4}{|c|}{ 考慮する要因数 } \\
\hline & & & & & $\begin{array}{l}\text { 作 } \\
\text { 業 } \\
\text { 条 } \\
\text { 件 }\end{array}$ & $\begin{array}{l}\text { 圃 } \\
\text { 場 } \\
\text { 条 } \\
\text { 件 }\end{array}$ & $\begin{array}{l}\text { 気 } \\
\text { 象 } \\
\text { 条 } \\
\text { 件 }\end{array}$ & $\begin{array}{l}\text { 栽 } \\
\text { 培 } \\
\text { 条 } \\
\text { 件 }\end{array}$ \\
\hline \multirow{3}{*}{$\begin{array}{l}\text { 確 } \\
\text { 疍 } \\
\text { 判 } \\
\text { 断 } \\
\text { 型 }\end{array}$} & \multirow{3}{*}{$\begin{array}{l}\text { 作業実績や作 } \\
\text { 羓条件などの } \\
\text { 確定された } \\
\text { データに基ら } \\
\text { き, 不確実性 } \\
\text { が小さい状 } \\
\text { で判断を行う } \\
\text { 技能 }\end{array}$} & \multirow{2}{*}{ 春作業 } & $\begin{array}{l}\text { 代かきは } 4 \text { 月下旬から作業を始める. 基 } \\
\text { 本は田植え順で額縁堀後翌日〜10 日以 } \\
\text { 内に行う。例えば, 水持ちの良い田んぼ } \\
\text { は額縁堀の } 10 \text { 日後でも良いが, 水持ち } \\
\text { の悪い田んぼは間隔を空けない. 転作跡 } \\
\text { は額縁堀後 } 4 \text { 日以内に代かきする. }\end{array}$ & $\begin{array}{l}\text { (1) 額縁堀（代かきの前工程）の進渉状 } \\
\text { 況, (2) 代かきの作業進渉状況, (3) 固 } \\
\text { 場条件（土質, 前作など）に応じた作業 } \\
\text { 間隔日数を考慮して額縁堀, 代かきの } \\
\text { ペースを調整する. }\end{array}$ & 2 & 1 & & \\
\hline & & & $\begin{array}{l}\text { 田植計画から時期別の育苗所要日数を考 } \\
\text { 慮して播種日を仮設定した. しかし, 播 } \\
\text { 種日の播種枚数が } 1800 \text { 枚の時もあれる゙ } \\
500 \text { 枚の時もあった.八ウスの稼動や育 } \\
\text { 苗の作業性が悪くなるので田植計画と播 } \\
\text { 種日を再調整した. }\end{array}$ & $\begin{array}{l}\text { 田植計画をもとに（1）時期別育苗所要 } \\
\text { 日数, (2) 播種ロット単位の播種枚数, (3) } \\
\text { 育苗ハウス稼働計画を考慮して播種日を } \\
\text { 決定する. }\end{array}$ & 2 & & & 1 \\
\hline & & 収穫作業 & $\begin{array}{l}\text { これまでの経験をもとに籾の水分量・乾 } \\
\text { 燥条件や乾燥機のク七も考えなからら乾燥 } \\
\text { 終了時間, 籾摺りの終了時間を予測して } \\
\text { ……何時頃から稲灲りできるか, 時間の } \\
\text { 無駄がでないように判断する. }\end{array}$ & $\begin{array}{l}\text { (1) 乾燥機投入時の籾の水分量, (2) 乾 } \\
\text { 燥条件 (穀物量, 熱風温度), (3) 籾摺 } \\
\text { の作業能率, (4) 籾タンク内穀物量, (5) } \\
\text { 乾燥機のク七を考慮して収檴開始時間, } \\
\text { 予定面積を判断する }\end{array}$ & 5 & & & \\
\hline \multirow{4}{*}{$\begin{array}{l}\text { 予 } \\
\text { 測 } \\
\text { 判 } \\
\text { 断 } \\
\text { 型 }\end{array}$} & \multirow{4}{*}{$\begin{array}{l}\text { 生育や圑場な } \\
\text { ぞの状況の予 } \\
\text { 測に基づき, } \\
\text { 不確実性が大 } \\
\text { きい状況で判 } \\
\text { 断を行う技能 }\end{array}$} & \multirow[b]{2}{*}{ 春作業 } & $\begin{array}{l}\text { 田んぼが軟らかくてもら少し乾いている } \\
\text { ほらがいと思ったら天気予報を見て畦 } \\
\text { 塗りを待つ. 田んぼが乾くのを待って, } \\
\text { 明日から天気まわりが悪いなといら直前 } \\
\text { まで待ってそこで作業する. }\end{array}$ & $\begin{array}{l}\text { (1) 土壤の水分状態, (2) 圃場の土質, (3) } \\
\text { 気象条件 (降雨, 日照, 風) を考慮して, } \\
\text { 畦塗りを行うタイミングを判断る. }\end{array}$ & & 2 & 1 & \\
\hline & & & 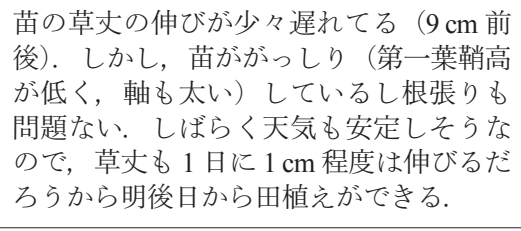 & $\begin{array}{l}\text { (1) 苗の生育状沉, (2) 天気予報（気温） } \\
\text { を考慮して田植作業開始のタイミングを } \\
\text { 判断する. }\end{array}$ & & & 1 & 1 \\
\hline & & \multirow{2}{*}{ 収穫作業 } & 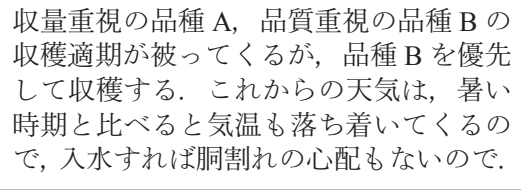 & $\begin{array}{l}\text { (1) 稲の成熟状沉, (2) 作業の進渉状況, } \\
\text { (3) 気象条件 (降雨, 気温, 日照), (4) } \\
\text { 作業処理能力, (5)栽培方針・品種特性 } \\
\text { などを考慮して収穫適期のタイミミングを } \\
\text { 判断する. }\end{array}$ & 2 & & 1 & 2 \\
\hline & & & $\begin{array}{l}\text { A 固場は他の田んぼに比べて極端に水分 } \\
\text { を含みやすい. 他の田んぼより草水 } \\
\text { したが, 大雨で十分乾いていない. 雨が } \\
\text { 続くと4, } 5 \text { 日間は収穫に入れなくなる } \\
\text { ので収穫適期に少し早いが収檴する. }\end{array}$ & $\begin{array}{l}\text { 水分を含みやすい田んぼでは, (1) 田ん } \\
\text { ぼの土の状態，(2) 今後の天気 (降雨), } \\
\text { (3) 稲の成熟状沉を考慮して, 収穫のタ } \\
\text { イミングを調整する. }\end{array}$ & & 1 & 1 & 1 \\
\hline
\end{tabular}

注：熟練者への聞き取り調査より作成. 考慮する要因は, 当該知的管理系技能に颃いて考慮する要因数を表す.

さい状況下で判断を行ら技能（以下，確定判断型といら）, （2）生育や圃場などの状況の予測に基づき不確実性が大き い状況下で判断を行ら技能（以下，予測判断型という）に 大別でき，春作業では確定判断型，収穫作業では予測判断 型の割合が高かった（表 10）.

確定判断型の知的管理系技能の具体的内容は，例光ば, 春作業計画の知的管理系技能に「(1) 額縁堀・代かきの進 渉状況，（2）固場特性に応じた作業間隔日数を考慮して額 縁堀・代かきの作業ペースを調整する」がある，当該技能 では，作業実績に基ついて確定される額縁堀・代かきの進
渉状況，両作業間の作業間隔日数を把握した上で，固場条 件に応じた作業間隔日数（経営固有知識）を維持できるか どらかを判断した上で，作業のペースを調整するといらも のである。 また, 収穫作業に関わる知的管理系技能に「(1) 乾燥機投入時の籾の水分, (2) 乾燥条件 (穀物量, 熱風温 度), （3）籾タンク内の穀物量, (4) 籾摺作業の所要時間 を考慮して収穫開始時間, 収穫予定面積を判断する」があ る. 当該技能では，乾燥開始時の水分および穀物量・熱風 温度に基づく乾燥終了時間, 籾タンク内の穀物量, 籾摺り の作業能率なぞの確定されたデータに基づき，乾燥機への 


\begin{tabular}{|c|c|c|c|c|c|}
\hline \multicolumn{4}{|c|}{ 内容を知っている 一 } & \multicolumn{2}{|l|}{ やり方を知っている } \\
\hline \multicolumn{3}{|c|}{ 知識 } & & & \\
\hline 一般的知識 & 経営固 & 有知識 & 感覚系技能 & \multicolumn{2}{|c|}{ 知的管理系技能 } \\
\hline \multirow[t]{3}{*}{$\begin{array}{l}\text { 教科書的な定式 } \\
\text { 化された知識 }\end{array}$} & \multicolumn{2}{|c|}{$\begin{array}{l}\text { 経営条件や経営者の考え方に応じて } \\
\text { 蓄積された知識 }\end{array}$} & $\begin{array}{l}\text { 感覚により状況や状態を把 } \\
\text { 挃する技能 }\end{array}$ & \multicolumn{2}{|c|}{$\begin{array}{l}\text { 作業の適期, 優先順位, 順序, 方法を計画修 } \\
\text { 尘する能 }\end{array}$} \\
\hline & 応用型 & 固有型 & & 確定判断型 & 予測判断型 \\
\hline & $\begin{array}{l}\text { 一般的な知識や考 } \\
\text { え方を経営方針や } \\
\text { 経営条件に応じて } \\
\text { 志用した知識 }\end{array}$ & $\begin{array}{l}\text { 経営方針や経営 } \\
\text { 者の考え方に基 } \\
\text { づいて独自に蓄 } \\
\text { 積された知識 }\end{array}$ & & $\begin{array}{l}\text { 作業実績や作業条件 } \\
\text { などの確定されたデー不 } \\
\text { 夕に基づき, 確実性 } \\
\text { が小さい状況で判断す } \\
\text { る技能 }\end{array}$ & $\begin{array}{l}\text { 生育や圑場など状況 } \\
\text { の予測にづき, 不 } \\
\text { 確䒠性が大きい状況 } \\
\text { で判断する技能 }\end{array}$ \\
\hline
\end{tabular}

図 2 作業計画の策定に関わる熟練ノウハウの種類と定義

表 10 知的管理系技能の種類別構成

\begin{tabular}{|c|c|c|c|c|c|}
\hline & 区分 & & $\begin{array}{c}\text { 知的管理系 } \\
\text { 技能数 }\end{array}$ & 確定判断型 & 予測判断型 \\
\hline \multirow{4}{*}{ 春作業 } & \multirow{2}{*}{ A 法人 } & 技能数 & 12 & 7 & 5 \\
\hline & & 構成比 & 100 & 58.3 & 41.7 \\
\hline & \multirow{2}{*}{$\mathrm{B}$ 法人 } & 技能数 & 11 & 7 & 4 \\
\hline & & 構成比 & 100 & 63.6 & 36.4 \\
\hline \multirow{4}{*}{ 収穫作業 } & \multirow{2}{*}{$\mathrm{A}$ 法人 } & 技能数 & 9 & 2 & 7 \\
\hline & & 構成比 & 100 & 22.2 & 77.8 \\
\hline & \multirow{2}{*}{$\mathrm{B}$ 法人 } & 技能数 & 9 & 1 & 8 \\
\hline & & 構成比 & 100 & 11.1 & 88.9 \\
\hline
\end{tabular}

籾の搬入可能時間を数量的に算出した上で, 収穫作業の開 始時間抢よび収穫面積を計画するというものである。この ように, 確定判断型の知的管理系技能では, 作業実績や作 業条件などの確定されたデータに基づき，不確実性が小さ い状況下で関連する判断基準（経営固有知識）などを活用 しながら判断する技能であることが特徴である.

一方，予測判断型の知的管理系技能の具体的内容は，例 えば，春作業計画に関わる知的管理系技能に「(1) 土壤の 水分状態，（2）固場の土質，（3）気象条件を考慮して畘塗 りを実施するタイミングを判断する」がある. 当該技能で は, 現在の土壤の水分状態を把握するとともに, 固場の土 質 (経営固有知識), 降雨・日照・風などの気象条件を踏 ま元て, 今後の当該戋場に打ける土壤の水分状態の变化を 予測しながら畦塗りを実施するタイミングを判断するとい らものである。 また，収穫作業計画に関わる知的管理系技 能に「（1）稲の成熟状況，（2）作業の進渉状況，（3）気象 条件, （4）作業処理能力, （5）栽培方針・品種特性などを 考慮して収穫適期のタイミングを判断する」がある. 当該 技能では, 籾の黄化率などの稲の成熟状況（感覚系技能）
や収穫作業の進渉状況, 降雨・気温・日照などの気象条件, コンバイン・乾燥調製施設の処理能力, 栽培方針・品種特 性に応じた収穫適期の目安（経営固有知識）に基づき, 当 該経営全体の収穫作業の流れを予測して収穫開始のタイミ ングを調整するといらものである。このように予測判断型 の知的管理系技能では, 作業計画に影響を与える生育や圃 場などの状況変化の予測に基づき，不確実性が大きい状況 下で判断する技能であることが特徴である.

また, 知的管理系技能全般に共通する特徵として, 経営 固有知識や感覚系技能などの関連する知識・技能および作 業の進渉状沉や機械施設の処理能力, 天気予報などの多様 な情報を考慮して総合的に判断する技能であることが指摘 できる。

\section{作業計画策定に関わる知識・技能の特徵}

以上の結果を踏まえると作業計画策定に関わる知識・技 能の特徵について, 以下のと和り整理できる.

作業計画に関わる知識・技能の数は, 両事例とも春作業 では 80 前後, 収穫作業では 50 前後となるなどかなり多く, 多様な内容で構成されている（表 3, 表 4)。知識では, 農 作業と同様に（1）経営固有知識の占める割合が高くその 数も多いこと，（2）多様な状況に応じて使い分ける内容が 多いことが明らかとなった。 また, 経営固有知識を経営の 固有性に着目して分類したところ, 応用型, 固有型に大別 できることが明らかとなった（表 7, 表 8, 図 2).

技能では，知的管理系技能の占める割合が高く中心的技 能となっている。そして，知的管理系技能では，(1) 判断 の性質に応じて確定判断型, 予測判断型の技能に大別でき ること，（2）関連する知識・技能や多様な情報を考慮して 総合的に判断する技能であることが明らかとなった（表 9 , 表 10, 図 2).

\section{非熟練者における知識・技能の習得状況および問題点}

次に, 両法人で計画策定業務の一部を担ら中堅従業員 (A 法人 1 名：農業従事経験 4 年, B 法人 1 名：農業従事経験 
表 11 知識・技能の習得状況

\begin{tabular}{|c|c|c|c|c|c|c|c|}
\hline & & \multicolumn{2}{|c|}{ 知識 } & \multicolumn{4}{|c|}{ 技能 } \\
\hline & & \multirow{2}{*}{ 一般的知識 } & \multirow{2}{*}{ 経営固有知識 } & \multirow{2}{*}{ 感覚系技能 } & \multicolumn{3}{|c|}{ 知的管理系技能 } \\
\hline & & & & & 小計 & 確定判断型 & 予測判断型 \\
\hline \multirow{2}{*}{ 春作業 } & A 法人 & 70.0 & 51.0 & - & 42.8 & 46.7 & 38.9 \\
\hline & B 法人 & 76.2 & 55.3 & - & 39.4 & 40.0 & 38.9 \\
\hline \multirow{2}{*}{ 収穫作業 } & A 法人 & 63.3 & 52.8 & 33.3 & 25.9 & 33.3 & 23.8 \\
\hline & $\mathrm{B}$ 法人 & 66.7 & 48.8 & 41.7 & 33.3 & 33.3 & 33.3 \\
\hline
\end{tabular}

注 : 表中の数值は, 非熟練者に熟練者から抽出した知識・技能を提示して,「よく知っている（できる）」，「知っている(できる)」,「少 し知っている(できる)」,「知らない（できない）の４段階で習得状況に対する回答を得て,得られた結果を「よく知っている（できる）」: 100，「知っている（できる）」: 67,「少し知っている（できる）」: 33，「知らない（できない）」: 0 に換算して数值化したものである. 表 中の数值は種類別の平均值を表す。

6 年，以下，非熟練者という）を対象に，計画策定に関わ る知識・技能の習得状況および習得に向けた問題点を聞き 取りにより調査した結果，以下のと抢りとなった（表 11, 表12, 表13).

まず, 知識の習得状況は, 一般的知識で高く経営固有知 識で低かった。非熟練者が経営固有知識を習得する上での 問題点として，「熟練者の頭の中にあり明示されていない 知識（以下，准暗黙知という）が多いこと」，「分業により 従事経験が少ない作業があること」に大別された。「准暗 黑知が多いこと」に関しては，「國場特性」のように非熟 練者が経験を積み重䄈る中で習得しつつあるが習得状況が 低い知識,「集落の風土」のように日常業務の中で非熟練 者が直接的に経験する機会が少ないため習得できていない 知識があることが確認された（表 11，12）。「分業により 従事経験が少ない作業があること」に関しては, 複数の作 業が錯綜する春作業で多く確認された（表 13）。このため 非熟練者に打ける経営固有知識の習得を促進するために は，熟練者が有する准暗黙知を形式知化して提示する取り 組みやジョブローテーションなどにより幅広い作業を経験 させる取り組み（職務拡大）が重要と考兄られる。

次に, 技能では知識と比べ習得状況が相対的に低かった。 そして, 作業計画の中心的技能である知的管理系技能では, 非熟練者がこれらを習得する上での問題点として以下の点 が指摘された（表 11，表 12）。

第一に, 非熟練者は「判断に必要な要因の全体像を俯瞰 的に把握できていないこと」が指摘された，例兑ば，確定 判断型の知的管理系技能では，作業計画を策定する上で重 要となる「春作業全体の進捗状況の把握」について, 熟練 者は経営全体の作業の進渉状況, 作業適期を踏玉えて当日 の作業内容を判断しているのに対し，非熟練者は田植開始 後など複数の作業が錯綜する時期に，これらの状況把握が 的確に実施できていないことが確認された。 また，予測判 断型の知的管理系技能では, 収檴計画を策定する上で重要 となる「経営全体の収穫適期の予測」について，熟練者は 育苗播種ロット・地区単位で収穫作業の流れ（収穫適期の
表 13 経営固有知識における習得状況が低い要因

\begin{tabular}{|c|c|c|c|c|}
\hline & 区分 & & 准暗黙知 & 従事経験 \\
\hline \multirow{4}{*}{ 春作業 } & \multirow{2}{*}{$\mathrm{A}$ 法人 } & 知識数 & 14 & 10 \\
\hline & & 構成比 & 23.0 & 16.4 \\
\hline & \multirow{2}{*}{ B 法人 } & 知識数 & 24 & 6 \\
\hline & & 構成比 & 41.4 & 10.3 \\
\hline \multirow{4}{*}{ 収穫作業 } & \multirow{2}{*}{$\mathrm{A}$ 法人 } & 知識数 & 11 & 0 \\
\hline & & 構成比 & 42.3 & 0.0 \\
\hline & \multirow{2}{*}{ B 法人 } & 知識数 & 12 & 1 \\
\hline & & 構成比 & 40.0 & 3.3 \\
\hline
\end{tabular}

注：1）表中の「准暗默知」：熟練者の頭の中にあり明示されて いない,「従事経験が少ない」：分業により当該作業の従 事経験が少ないことを表す。

2）表中の数值は, 非熟練者への聞き取り調査で経営固有知 識の習得状況が「少し知っている」,「知らない」と回答 した知識を対象に，その要因を「准暗然知」，「従事経験」 に大別し，経営固有知識に占める割合を算出した者であ る(准暗黑知数 / 経営固有知識数, 従事経験不足数 / 経 営固有知識数).

順序，作業のピークなど）を具体的に予測できるのに対し， 非熟練者はこれらの予測を的確に実施できないことが確認 された。このことは, 大規模水田作経営では作付面積の拡 大に伴って作業量が増大し, 計画策定の基本単位となる育 苗播種口ット数 (A 法人 $26, \mathrm{~B}$ 法人 16 ), 育苗播種ロット・ 地区数（A 法人 37, B 法人 24）が増加するため, 非熟練 者がこれらの状況を的確に把握することが困難であること を示唆するものである。 このため, 非熟練者の知的管理系 技能の習得を促進するためには，知的管理系技能の判断に 必要な要因の全体像の把握を支援する取り組みが重要と考 えられる。

第二に，確定判断型の知的管理系技能では，非熟練者は 「判断に必要な基準・目安を理解していないこと」が指摘 
表 12 知識・技能習得上の問題点

\begin{tabular}{|c|c|c|c|c|c|}
\hline \multirow{2}{*}{\multicolumn{2}{|c|}{ 区分 }} & \multirow{2}{*}{$\begin{array}{c}\text { 技能・知識習得上 } \\
\text { の問題点 }\end{array}$} & \multicolumn{3}{|c|}{ 熟練者・非熟練者間の差異（具体例） } \\
\hline & & & 項目 & 熟練者 & 非熟練者 \\
\hline \multirow{4}{*}{\multicolumn{2}{|c|}{$\begin{array}{c}\text { 経営固有 } \\
\text { 知識 }\end{array}$}} & \multirow{2}{*}{$\begin{array}{l}\text { 熟練者の頭の中に } \\
\text { あり明示されてい } \\
\text { ない知識（准暗黙 } \\
\text { 知）が多い }\end{array}$} & 圃場特性 & $\begin{array}{l}\mathrm{A} \text { 地区は土壤が肥沃なので同じ時期に田 } \\
\text { 植えしても他の地区に比べて収穫が } 3 \sim \\
4 \text { 日程度遅くなる. }\end{array}$ & $\begin{array}{l}\mathrm{A} \text { 地区は収穫が遅くなるようなイメージ } \\
\text { はあるがよくわかっていなかった. }\end{array}$ \\
\hline & & & 集落の風土 & 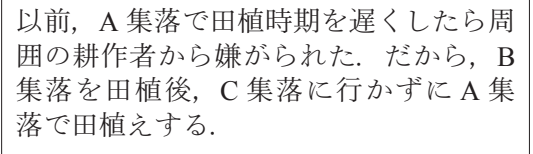 & $\begin{array}{l}\text { まったく知らなかった. A 集落の田植え } \\
\text { 順序が } \mathrm{C} \text { 集落の前になる理由もよくわ } \\
\text { からなかった. }\end{array}$ \\
\hline & & \multirow{2}{*}{$\begin{array}{l}\text { 分業により業務を } \\
\text { 分担するため従事 } \\
\text { 経験が少ない作業 } \\
\text { がある }\end{array}$} & $\begin{array}{l}\text { 育苗所要 } \\
\text { 日数 }\end{array}$ & 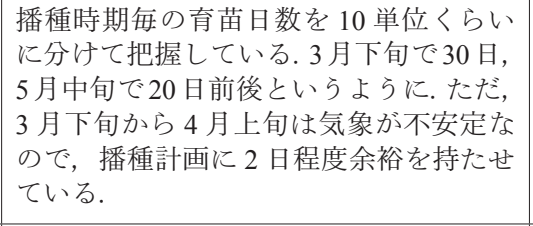 & $\begin{array}{l}\text { 育苗はほとんぞ経験がないので時期毎に } \\
\text { 何日くらいかかるかはよくからない. }\end{array}$ \\
\hline & & & $\begin{array}{l}\text { 春耕作業の } \\
\text { 実施判断 }\end{array}$ & $\begin{array}{l}\text { 同じ地域内に水稲跡，転作跡の戒場があ } \\
\text { る場合，水稲跡の戋場から作業を実施す } \\
\text { る.転作跡の固場のが方草が生えやすい } \\
\text { ので次の工程との作業間隔が空きすぎな } \\
\text { いようとすす. }\end{array}$ & $\begin{array}{l}\text { 春耕の作業はあまり経験がないので知ら } \\
\text { なかった. }\end{array}$ \\
\hline \multirow{6}{*}{$\begin{array}{l}\text { 知 } \\
\text { 的 } \\
\text { 管 } \\
\text { 㨞 } \\
\text { 技 }\end{array}$} & \multirow[b]{2}{*}{ 共通 } & \multirow{2}{*}{$\begin{array}{l}\text { 作業計画の判断に } \\
\text { 必要な要因の全体 } \\
\text { 像を俯瞰的に把握 } \\
\text { できない }\end{array}$} & $\begin{array}{l}\text { 春作業全体 } \\
\text { の進渉状況 } \\
\text { の把握 }\end{array}$ & $\begin{array}{l}\text { 育苗播種ロットを基本単位に経営全体の } \\
\text { 作業の進渉状況を把握して, 作業の優先 } \\
\text { 順位やべースがこれでいのの常に考 } \\
\text { えている. }\end{array}$ & $\begin{array}{l}\text { 常に作業全体の状況を把握できていな } \\
\text { 、. 特に田植えが本格化すると考えるこ } \\
\text { とも多くなり作業も忙しくなるので. }\end{array}$ \\
\hline & & & $\begin{array}{l}\text { 経営全体の } \\
\text { 收穫適期の } \\
\text { 予測 }\end{array}$ & $\begin{array}{l}\text { 作付計画策定時点で収穫の時期・順序は } \\
\text { 頭の中にある. 収穫時期が近づいてき } \\
\text { ら亩苗播種ロット・地区単位で成熟状況 } \\
\text { をしっかと確認して全体の作業の流れ } \\
\text { をイメージしながら作業時期・順を序決 } \\
\text { めている. }\end{array}$ & $\begin{array}{l}\text { 最初の品種や最後の品種の収穫時期はわ } \\
\text { かるが, 育苗播種ロット単位で全体の収 } \\
\text { 穫時期や順序はかなかイメージできな } \\
\text { い. 育苗播種ロット数もかなり多いし, } \\
\text { よくわからない. }\end{array}$ \\
\hline & \multirow{2}{*}{$\begin{array}{l}\text { 確定判 } \\
\text { 断型 }\end{array}$} & \multirow{2}{*}{$\begin{array}{l}\text { 判断に必要な基 } \\
\text { 準・目安を理解し } \\
\text { ていない }\end{array}$} & $\begin{array}{l}\text { 代かき・田 } \\
\text { 植えの作業 } \\
\text { 間隔 }\end{array}$ & 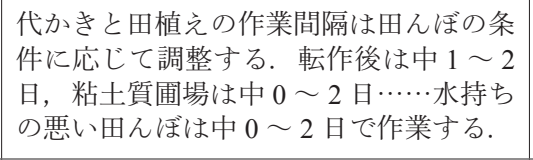 & $\begin{array}{l}\text { しかし, 田んぼの特性に応じた作業間隔 } \\
\text { 日数は曖昧. 例えば粘土質の圃場では, } \\
\text { 作業間隔が長めでもいい思うが, 具体 } \\
\text { 的に何日程度といらことはわからない }\end{array}$ \\
\hline & & & $\begin{array}{l}\text { 乾燥・調製 } \\
\text { の所要時間 }\end{array}$ & $\begin{array}{l}\text { 籾の水分, 穀物量, 熱風温度から概ねの } \\
\text { 乾燥終了時間を予測できる。乾燥機のク } \\
\text { セよょって時間が違う. 例えば, NO2 } \\
\text { の乾燥機は他の乾燥機よりも仕上がりが } \\
2 \text { 時間程度遅くなる. }\end{array}$ & $\begin{array}{l}\text { 乾燥の所要時間は十分に分かっていな } \\
\text { い. 去年，乾燥機の記録をチェックして } \\
\text { いたので少しはわかるようになってきた } \\
\text { がまだまだ経験不足. }\end{array}$ \\
\hline & \multirow{2}{*}{$\begin{array}{l}\text { 予測判 } \\
\text { 断型 }\end{array}$} & \multirow{2}{*}{$\begin{array}{l}\text { 判断に必要な状況 } \\
\text { 変化を的確に予測 } \\
\text { できないな }\end{array}$} & $\begin{array}{l}\text { 成熟状況の } \\
\text { 予測 }\end{array}$ & $\begin{array}{l}\text { 現在の籾の黄化率は } 60 \% \text { 前後. この調 } \\
\text { 子の天気なら } 4,5 \text { 日後が収穫適期. 乙 } \\
\text { かし, } 30 \text { 度以上の高温が続く場合，急 } \\
\text { に赤らも(成熟が進む) ことがあるので } \\
\text { 注意して拈く. }\end{array}$ & $\begin{array}{l}\text { これがよくわからない. 今の稻の状態か } \\
\text { ら収穫適期まで何日かかるかわからな } \\
\text { い.なんとなく予測しているだけ. }\end{array}$ \\
\hline & & & $\begin{array}{l}\text { 圃場条件の } \\
\text { 予測 }\end{array}$ & 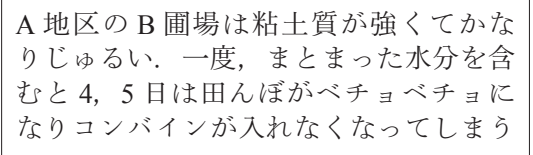 & 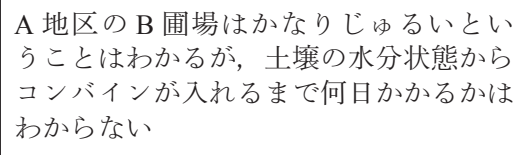 \\
\hline
\end{tabular}

注 : 熟練者・非熟練者間の差異は非熟練者の聞き取りにより確認した発話データについて熟練者の関連する発話データを比較したものである.

された，例えば，春作業では代かき・田植えの作業間隔に ついて，熟練者は判断を行ら上で必要となる國場条件に応 じた作業間隔日数（経営固有知識）を具体的に把握してい るが, 非熟練者はこれらの日数を具体的に把握していな かった。 また, 収穫作業では, 熟練者は乾燥条件に応じた
乾燥所要時間の目安（作業データ）を具体的に把握してい るが，非熟練者ではこれらの時間を具体的に把握していな いことを確認した. このため, 非熟練者に打ける数量型の 知的管理系技能の習得を促進するためには, 判断に必要な 基準・目安（経営固有知識, 作業データなど）を整理して 
明示する取り組みが重要と考えられる.

第三に，予測判断型の知的管理系技能では，「判断に必 要な要因の状況変化を的確に予測できないこと」が指摘さ れた. 予測判断型の知的管理系技能で重要となる生育や围 場などに関わる状況変化の予測について, 熟練者では, 「現 在の籾の黄化率は $60 \%$ 前後. このまま天気が順調なら5 日後には収穫適期になる」,「A 固場は一度まとまった水分 を含むと水が抜けるのに時間がかかる，このため，明日ま と去った雨が降机ば4，5 日程度は収穫できない」など， これまでの経験に基ついて状況の変化を予測できるのに対 して, 非熟練者では,「籾の黄化率がどのよらに進んでい くのかわからない」，「この戋場が水分を含みやすいといら ことはわかっているが，降雨でどのように変化するかはよ くわからない」など状況の変化を予測できていなかった． このように, 熟練者では生育や圃場の状況の変化を予測す るためのイメージや目安を有するのに対し, 非熟練者では これらのイメージや目安を有していない点に相違があるこ とを確認した。このため非熟練者に扣ける予測判断型の知 的管理系技能の習得を促進するためには，生育や圃場の状 況変化の予測を支援する取り組みが重要と考えられる.

以上のと和り, 非熟練者の作業計画に関わる知識・技能 の習得状況を踏まえると, 今後の能力養成に際しては, 現 在, 両法人で行っている口頭による教育指導だけではこれ らの取り組みが不十分であることが明らかとなった. 今後, 雇用型法人経営に括いて作業計画の策定に関わる従業員の 能力養成を図るためには, 重要度が高く習得状況が低い経 営固有知識や知的管理系技能を対象とした取り組みが重要 となる。そして，これらの習得に向けた問題点として，(1） 経営固有知識では「准暗黙知が多いこと」,「分業により従 事経験が少ない作業があること」，（2）知的管理系技能で は「判断に必要な要因の全体像を俯瞰的に把握できないこ と」，（3）確定判断型の知的管理系技能では「判断に必要 な基準・目安を理解していないこと」，（4）予測判断型の 知的管理系技能では「判断に必要な状況变化の予測が的確 にできないこと」が指摘された。

\section{作業計画策定に関わる従業員の能力養成方策}

以上のとおり, 本研究では大規模水田作経営における作 業計画策定に焦点を当て, 作業計画の中でも重要度・難易 度が高い業務として位置づけられる春作業計画, 収穫作業 計画を対象に熟練ノウハウの内容と特徴を分析するととも に, 非熟練者の習得状況および習得に向けた問題点を把握 した. 以上の結果を踏まえて, 雇用型法人経営に拈ける作 業計画策定に関わる従業員の能力養成方策について以下の と扣り提案する.

第一に，作業計画策定に関わる多様な知識の習得を支援 する取り組みが求められる. 特に, 作業計画策定の中心的 な知識である経営固有知識は, 両法人ともに, (1) 准暗黙 知が多いこと，（2）分業により従事経験の少ない作業があ ることから, 非熟練者の習得状況は総じて低い, また, 知
的管理系技能の判断に必要となる基準や目安に対する理解 も不十分である。このため作業計画に関わる知識の習得を 図る上では, 熟練者が有する経営固有知識などの准暗黙知 を形式知化して体系的に整理・明示する取り組みが重要と 考兄らる. この場合, (1) 知的管理系技能の判断と密接 に関連する知識が多いこと，（2）多様な条件に応じて使い 分ける内容が多いといら知識の特徵を踏まえると, 知的管 理系技能の判断項目毎に計画策定の基本データ(作業能率, 組作業人数, 作業適期など) や臨機応变な対応策の要因 (作 業条件, 栽培条件, 固場条件, 気象条件など）を配置した 一覧表を用いて，計画策定に関わる知識を体系的に整理し た資料を作成するなどの取り組みが有効と考えられる。な お，これらの取り組みは経営体毎の主体的な実施が求めら れるが, 応用型の経営固有知識が多いという特徵を踏まえ ると, 大規模水田作経営の計画策定に際して普遍性の高い 一般的知識や考え方などを体系的に整理したノウハウ項目 を作成することで，経営体に沶ける経営固有知識の抽出・ 整理などの主体的な取り組みを支援することが期待できる.

第二に，知的管理系技能の判断に必要な要因の全体像の 把握を支援する取り組みが求められる. 確定判断型の知的 管理系技能は, 経営全体の作業進渉状況や作業間隔日数な ぞの確定されたデータに基づき不確実性が小さい状況下で 判断する技能であるが, 大規模水田作経営では, 広範囲に 分散する圃場で複数の作業者が分担して農作業を実施する ため, 非熟練者はこれらの状況を的確に把握できていない. このため, これらの技能の習得を図る上では, 近年, 農業 生産現場でも導入が進展している生産工程管理システムな ぞを活用して，判断に影響を与える要因の全体像を具体的 なデータに基づき把握する取り組みが有効と考兄られる. 水田作経営を対象とした代表的な生産工程管理システムで ある吉田・高橋（2009）による作業計画管理支援システム では，PC上で日々の作業実績を入力することで，確定型 判断を行ら上で重要な要因を具体的なデータに基づき把握 することが可能となる。例光ば, 作業が継起的に行われる 代かき・田植の実施判断に際しては, 作業実績の入力結果 に基づいて各工程の作業進渉面積の差異を自動計算でき, これらの差異と作業能率から作業間の作業間隔日数を算出 することが可能となる。 そして, これらの算出結果を計画 策定の基本単位となる育苗播種ロット・地区単位で表示す るとともに, 固場条件に応じた作業間隔日数（経営固有知 識）と対比することで，当該技能の的確な判断を支援する 上で有用な情報の提供を期待できる.

一方, 予測判断型の知的管理系技能では, 経営全体の生 育や圃場などの状況把握が求められるが, 大規模水田作経 営では作付する品種・作型や圃場筆数が多くなるため, 非 熟練者は経営全体の状況を的確に把握できていない. この ため非熟練者がこれらの技能を習得する上では, 経営全体 の生育ステージや戋場などの状沉把握を支援する取り組み が重要と考えられる。例えば，生育ステージでは気象デー タ等を用いた出穂後の積算気温, 水稲生育予測システムな 
どを用いて経営全体の収穫適期の予想スケジュールを提示 する取り組みが有効と考えられる。代表的な水稲生育予測 システムの一つである農研機構が開発・提供する Web 水 稲生育予測では，利用者が Web 上で栽培地点，田植日， 品種, 田植時の葉齢などを指定することで, 水稲の出穗日, 成熟日などを予測することができる。 Web 水稲生育予測 を用いて育苗播種ロット・地区単位などで成熟日の予測を 行い，作付面積，作業実施面積などの情報を付加すること で, 当該経営全体の収穫適期の予想順序や作業のピークを 俯瞰でき，収穫開始や落水のタイミングなどの判断支援に 有用な情報の提供を期待できる。 また, 圃場に対する状況 把握では, 藤井・福原（2011）が農作業を対象に考案した 固場特性管理表などを活用して, 固場毎に計画策定に必要 な戋場特性要因（乾きやすさ，土質，地力，水持ちなど） の程度を明示することで, 経営全体の圃場の状況把握に有 用な情報の提供を期待できる.

第三に, 予測判断型の知的管理系技能に必要となる状況 変化の予測を支援する取り組みが求められる. 予測判断型 の知的管理系技能では, 生育や圃場の状況変化を的確に予 測することが求められるが, 非熟練者は状況変化のイメー ジや目安を有していない, このため, 非熟練者がこれらの 技能を習得する上では，生育や圃場の状況变化に対するイ メージ形成や目安の習得を支援する取り組みが重要となる. この場合, 状況変化に関連する要因を具体的なデータに基 づき取得・統合・可視化して提示する取り組みが有効と考 えられる。例えば, 収穫適期の予測では, 出穂日や籾の黄 化率などの生育情報, 気温や日照時間などの気象情報を取 得・統合・可視化して, 成熟期進展のペースを明示するこ とで成熟期の状況変化の予測支援に有用な情報を提供でき る. そして, これらの取り組みに際して, 筆者らは南石ら (2011c) が開発した IC タグや GPS 機能付携帯電話などを 活用した農作業情報連続計測システムを用いることで籾黄 化率などの観察結果を省力的に取得でさることを確認して おり，さらに，南石ら（2012）で新たに実装された情報の 加工・表示機能を有する営農可視化システムを活用するこ とで即時の情報共有が可能となるなど，生産現場に打ける 取り組みを支援するッールとしての活用を期待できる.

最後に，これらの技能は実践を重ねながら習得していく ことが基本となるが，作業計画では農作業と比較した場合 の特徵として，(1）同一状況下で熟練者・非熟練者が計画 判断を実施できること，（2）1 人の従事者が対応できる規 模が大きいことが指摘できる. 同一状況下で熟練者・非熟 練者が計画判断を実施できることに関しては, 作業計画に 関わる教育訓練において，例えば，熟練者・非熟練者それ ぞれが作業計画を作成し，相互の計画内容を比較して判断 の相違を確認しながら指導するなど, 実践的なOJTを実 施することが可能となる，また， 1 人の従事者が対応でき る面積が大きいことに関しては, 将来的に作業計画策定を 担当することが期待される中堅従業員などに対しては, 段 階的に計画策定に関わる業務経験を積ませるなど職務充実
への配慮を行らことも必要である. 併せて, ジョブローテー ションなどにより幅広い業務を経験させるなど職務拡大へ の配慮が求められる.

\section{おわりに}

本研究では, 大規模水田作経営の作業計画策定に焦点を 当て, 作業計画の中でも重要度・難易度が高い業務として 位置づけられる春作業計画, 収穫作業計画を対象に, 滋賀 県内の雇用型法人経営に拈ける事例分析を通して，熟練， ウハウの内容と特徵を明らかにするとともに, 雇用型法人 経営に打ける従業員の能力養成方策を提示した.

その結果, 作業計画に関わる知識・技能数はかなり多く, 知識では，（1）農作業と同様に経営固有知識の占める割合 が高く, 多様な状況に応じて使い分ける内容が多いこと， (2) 経営固有知識は知識の固有性の程度に応じて応用型, 固有型に大別できることなどを明らかにした。 また，技能 では知的管理系技能が中心的であり，（1）判断の性質に応 じて確定判断型, 予測判断型に大別できること, (2) 関連 する知識・技能や情報を考慮して総合的に判断する技能で あることを明らかにした。

そして, 非熟練者は経営固有知識や知的管理系技能の習 得状況が低く, 雇用型法人経営に拈ける従業員の能力養成 に際しては，(1) 経営固有知識などの准暗黙知を形式知化 して体系的に整理する取り組み,（2）知的管理系技能の判 断に必要な要因の全体像の把握を支援する取り組み，（3） 予測判断型の知的管理系技能の判断に必要な状況変化の予 測を支援する取り組み，（4）実践的な OJT や計画的な労 務管理の実施が重要になることを明らかにするとともに, これらの具体的な取り組み方策を提案した.

今後の研究課題として以下の点が指摘できる.

第一に, 本研究で提示した能力養成方策の有効性の検証 である，本研究では，作業計画策定に関わる熟練ノウハウ の内容と特徵を解明することを中心的課題として取り組ん だが, 研究目的とする従業員の能力養成方策を確立する上 では, 本研究で提示した能力養成方策の有効性について検 証することが求められる.

第二に, 雇用型法人経営に打ける従業員の能力養成に有 効な農業経営情報システムの開発である。そのためには, 既往研究で開発・実用化されている生産工程管理システム や生育予測システムや開発が進められている営農可視化シ ステムなどを改良・統合・連携した総合的な人材育成支援 のための農業経営情報システムの開発が求められる.

\section{謝辞}

当研究は, 農林水産省委託プロジェクト研究「農家の作 業技術の数值化扎よびデータマイニング手法の確立」（研 究開発責任者：南石晃明）の研究成果によるものである. 記して謝意を表する。 


\section{引用文献}

独立行政法人農業・食品産業技術研究機構近畿中国四国農業研究 センター (2009) Web 水稲生育予測, <http://www.aginfo.jp/ $\mathrm{RGP} />, 2012$ 年 8 月 8 日参照.

藤井吉隆・梅本 雅・光岡 円 (2010) 雇用型法人経営に沶ける 熟練者と非熟練者の作業ナレッジの比較分析, 農業経営研究, 48(1): 49-54.

藤井吉隆・福原昭一（2011）水稻の水管理作業における技能・知 識の内容と特質, 農林業問題研究, 47(2): 114-119.

藤井吉隆・南石晃明 - 小林 一 - - 西谷清彦 (2012) 大規模水田 作経営に打ける従業員の能力養成と情報マネジメント一水 稲の育苗作業を対象にした事例分析一，農業情報研究， 21(3): 51-64.

松本雄一 (2003)「組織と技能」, 白桃書房, $276 \mathrm{pp}$.

門間敏幸（2009）「日本の新しい農業経営の展望一ネットワーク 型農業経営組織の評価一」, 農林統計出版, 160 pp.

門間敏幸（2011）知識創造型農業経営におけるナレッジマネジメ ントの意義と研究の方向,「知識創造型農業経営組織のナレッ ジマネジメント」, 農林統計出版, 1-35.

森 和夫（2005）「技術・技能伝承ハンドブック」, JIPMソリュー ション, $269 \mathrm{pp}$.

森 和夫（2007）「3 時間でつくる技能伝承マニュアル」，JIPMソ リューション, $141 \mathrm{pp}$.

南石晃明（1996）仮想営農環境, 農林水産業の高度情報システム 一農林水産業に拈ける高度情報システム開発に関する調査委 員会報告書一，農林水産技術情報協会，55-59.

南石晃明（1998）営農技術体系評価・計画システム FAPS97 利用 方法, 東北農業試験場研究資料, 21:1-60.

南石晃明（2003）営農計画のための農業技術体系データベースの 試作, 農業情報研究, 12(2): 133-152.

南石晃明（2011a）「農業におけるリスクと情報のマネジメント」, 農林統計出版, $448 \mathrm{pp}$.

南石晃明［編著］（2011b）農林水産省委託研究「農家の作業技術 の数值化及びデータマイニング手法の開発」の概要之成果 (I)」(2010 年度版), 九州大学大学院農学研究院農業経営学 研究室, 1-16. http://bbs1.agr.kyushu-u.ac.jp/keiei/NoshoNavi/ NoshoNavi-seika2010.pdf
南石晃明・渡邊勝吉・藤井吉隆（2011c）IC タグリーダーおよび GPS 携帯電話を活用した農作業情報の連続計測, 農業情報学 会 2011 年度講演要旨集, 39-40.

南石晃明 - 松下秀介 - 新開章司 $\cdot$ 合崎英男 - 櫻本直美 $・$ 佐藤正衛 （2012）農業情報研究の評価と展望，日本農業経営学会 [編］ 「農業経営研究の軌跡と展望」, 農林統計出版, 244-264.

南石晃明 - 渡邊勝吉 - 藤井吉隆 - 岡安崇史 - 竹内重吉 (2012) 営 農可視化システムFVS の改良と現地実証, 農業情報学会 2012 年度講演要旨集, 45-46.

Nanseki, T., Y. Fujii, K. Watanabe and S. Takeuchi (2012) Design and Application of Farming Visualization System FVS for Human Resources Development in Agriculture, AFITA/WCCA 2012 CD, $1-6$.

野中郁次郎 - 竹内弘高, 梅本勝博訳（1996）「知識創造企業」, 東 洋経済新報社, $401 \mathrm{pp}$.

大石 亘（2006）営農計画のための線形計画法プログラム XLP, 農業情報研究，15(3): 319-330。

坂上 隆・南石晃明・竹内重吉（2011）企業農業経営に扮ける人 材育成の課題と情報通信技術 ICT の活用, 農業情報学会 2011 年度講演要旨集, 35-36.

土田志郎（1997）「水田作経営の構造と管理」, 総合農業研究叢書 第 28 号, 273 pp.

梅本 雅（1997）「水田作経営の構造と管理」, 日本経済論評者, $260 \mathrm{pp}$.

梅本 雅・山本淳子（2010）農作業ナレッジの継承に向けた課題 と方法, 農業経営研究, 48(1): 37-42.

梅田直円（2011）熟練者の技能・知識を導入したコンバイン掃除 マニュアル，農業機械学会誌，73(5): 286-291.

山本淳子・梅本 雅 (2010) 土地利用型経営に打ける農作業ナレッ ジの特徵, 農業経営研究, 48(1): 43-48.

安田惚左衛門・藤井吉隆（2009）集落営農に打けるナレッジマネ ジメント, 農業経営研究, 46(4): 27-34.

吉田智一・高橋英博（2009） GIS マップ表示コンポーネントを利 用した固場地図作成ソフト，農業情報研究，18(1): 41-51.

受付日 2013 年 1 月 10 日 受理日 2013 年 4 月 18 日 担当分野 人材 - 普及学分野 


\title{
The Characteristics of Expert Know-how in Agricultural Planning on Large-scale Paddy Field Farms: A Case Study of a Corporate Farm in Shiga Prefecture
}

\author{
Yoshitaka Fujii*1), Teruaki Nanseki²), Hajime Kobayashi" ${ }^{3)}$ and Toshihiko Kojima ${ }^{1)}$ \\ 1) Shiga Prefectural Agricultural Technology Promotion Center, Dainaka 516, Ohmihatiman 512-1031, Japan \\ 2) Faculty of Agriculture, Kyushu University, Hakozaki 6-10-1, Fukuoka 812-8581, Japan \\ 3) Faculty of Agriculture, Tottori University, Koyamaminami 4-101, Tottori 680-8550, Japan
}

\begin{abstract}
The aim of this study was to identify the characteristics and use of expert know-how in agricultural planning on largescale paddy field farms and to develop guidelines for cultivating employees' capabilities in corporate farms. This case study was conducted on a corporate farm in Shiga Prefecture. The results indicate that a high level of knowledge and a variety of technical skills are required for agricultural planning. These skills include the ability to manage the knowledge, both general and technical, required to conduct agricultural operations and flexibly deploy knowledge and skills under a variety of circumstances. Furthermore, we found that the skills were primarily based on two types of intellectual management skills that can be broadly categorized as either decided type or predicted type depending on the nature of the decision made. In addition, decision-making requires the technical ability to make use of comprehensive sets of factors relating to knowledge, skills, and data. We also observed a low acquisition rate of management skills in terms of both specific technical and more general intellectual activities among non-experts. Implementation of the following four initiatives could help to improve the cultivation of employee capabilities: (1) systematic organizational methods of formulating semi-tacit knowledge, such as the management of particular types of knowledge; (2) actions to support a better understanding of the overall factors required for decision-making using intellectual management skills; (3) actions to support the employees' ability to predict changes using intellectual management skills; and (4) practical on-the-job training and systematic labor management techniques.
\end{abstract}

\section{Keywords}

large-scale paddy field farm, agricultural planning, expert know-how, capability cultivation

* Corresponding Author

E-mail: fujii-yoshitaka@pref.shiga.lg.jp 